\title{
Diversified crop rotations enhance groundwater and economic sustainability of food production
}

\author{
Xiaolin Yang ${ }^{1}$ (D) | Tammo S. Steenhuis ${ }^{2}$ ｜ Kyle Frankel Davis ${ }^{3,4}$ | Wopke van der Werf ${ }^{5}$ | \\ Coen J. Ritsema $^{6}$ | Steven Pacenka ${ }^{2}$ | Fusuo Zhang ${ }^{7}$ | Kadambot H. M. Siddique ${ }^{8}$ | \\ Taisheng $\mathrm{Du}^{1}{ }^{1}$ \\ ${ }^{1}$ College of Water Resources \& Civil Engineering, China Agricultural University, Beijing, China \\ ${ }^{2}$ Department of Biological and Environmental Engineering, Riley-Robb Hall, Cornell University, Ithaca, New York, USA \\ ${ }^{3}$ Department of Geography and Spatial Sciences, University of Delaware, Newark, Delaware, USA \\ ${ }^{4}$ Department of Plant and Soil Sciences, University of Delaware, Newark, Delaware, USA \\ ${ }^{5}$ Crop Systems Analysis Group, Wageningen University, Wageningen, The Netherlands \\ ${ }^{6}$ Soil Physics and Land Management Group, Wageningen University, Wageningen, The Netherlands \\ ${ }^{7}$ College of Resources and Environmental Science, National Academy of Agriculture Green Development, China Agricultural University, Beijing, China \\ ${ }^{8}$ The UWA Institute of Agriculture, The University of Western Australia, Perth, WA, Australia
}

\section{Correspondence}

Xiaolin Yang, College of Water

Resources \& Civil Engineering, China

Agricultural University, Beijing 100083,

China.

Email: yangxiaolin429@cau.edu.cn

\section{Funding information}

National Natural Science Foundation of China, Grant/Award Number: 32071975,

51861125103 and 31601267; Hebei

Province Key Research and Development Program of China, Grant/Award Number: 20326411D-1

\begin{abstract}
Earth's water resources are critical for supporting livelihoods and food security but are being increasingly overexploited to support global agriculture. Diversifying cropping systems could potentially resolve unsustainable water use but trade-offs with other aspects of sustainability and food security have not yet been assessed. We performed a detailed analysis of 31 different field crop rotations conducted during 19902019 in the North China Plain, to assess the potential impact of crop diversification on actual evapotranspiration $\left(E T_{a}\right)$, changes in regional groundwater table, grain yield, economic output, and water use efficiency (WUE) and to identify configurations that can achieve co-benefits across multiple dimensions. We found that a combination of lowering the cropping index (i.e., harvest frequency), incorporating fallow periods, and introducing higher-value crops into the currently dominant winter wheat-summer maize double cropping system can reduce growing season $E T_{a}$ by as much as $31 \%$, mitigate groundwater decline by $19 \%$ or more, and increased economic output and economic WUE by more than $11 \%$ and $3 \%$, respectively. We also found that multiple diversified wheat-maize-based rotations-all with rotation lengths greater than 2 years-achieve co-benefits across all evaluated dimensions. This study provides new empirical evidence of the opportunities for diversified crop rotations to balance the multiple objectives of food production, sustainable groundwater use, and farmer profitability. Extending this solution to other water-stressed agricultural regions
\end{abstract}


could be an effective strategy in achieving more sustainable food production system globally.

\section{K E Y W O R D S}

crop productivity, diversified crop rotations, economic output, groundwater use, North China Plain

\section{1 | INTRODUCTION}

Groundwater delivers water for nearly 2 billion people worldwide, supplies more than $40 \%$ of irrigation water, and enables $13 \%$ of total food production (de Graaf et al., 2019), by overcoming local rainfall limits. Groundwater use permits large-and small-scale growers to increase agricultural production (Davis et al., 2017). It provides increased food security globally and could lead to healthier diets with proper planning (Willett et al., 2019). Groundwater resources are frequently and increasingly overexploited in many important agricultural areas, including the California Central Valley, the High Plains aquifer in the US Midwest, the Middle East, the Indus, Ganges basins, and the North China Plain (NCP) (Famiglietti, 2014).

China has been effective in increasing food availability and decreasing poverty due mainly to the increased grain production in the NCP. As the breadbasket of China, the NCP accounts for $23 \%$ of China's total grain production during the past four decades (National Bureau of Statistics of China, 2019a) (Figure 1a, Figure S1)-including 51\% of the nation's wheat, $35 \%$ of its maize, and a large fraction of other key crops such as peanuts and soybeans (National Bureau of Statistics of China, 2019a) (Figure 1b, Figure S2), and agriculture is responsible for $62-70 \%$ of the region's water usage (China Water Resources Bulletin, 2019). The growing dominance of wheat and maize production in the NCP is in large part the result of China's decades-long self-sufficiency initiatives to provide sufficient calories to the local people. In the 1950s, one rainfed grain crop was grown annually in this region, and the groundwater level remained close to the surface. The introduction of groundwater pumping for irrigation in the 1960s then enabled two crops per year-winter wheat (Triticum aestivum) and summer maize (Zea mays) (Luo et al., 2018). Since the 1980s, the intensive winter wheat-summer maize double cropping system ("wheatmaize" hereafter) has come to dominate the NCP, occupying $70 \%$ of the area's arable land (National Bureau of Statistics of China, 2019a) (Figure 1c,d, Figure S3) and consuming $700-1000 \mathrm{~mm}$ year $^{-1}$ of water (Liu et al., 2001; Yang et al., 2019). Water consumption exceeds average annual precipitation (667 mm; range 391-986 mm) (Figure 1e), 60\%-70\% of which arrives during the summer (June to September) (Figure S4). Winter wheat itself-grown from early October to mid-June-requires 100-300 mm of groundwater-sourced irrigation to satisfy crop water demands beyond what is supplied seasonal rainfall (Sun et al., 2019; Yang et al., 2019). Overuse of irrigation is depleting groundwater throughout the region, as seen in Cangzhou, Hengshui, and Xingtai where rates of decline have reached 1.5-2.2 $\mathrm{m} \mathrm{year}^{-1}$ (China Water Resources Bulletin, 2019) (Figure 1f, Figure S5). These unsustainable trends have meant that the NCP now hosts the deepest groundwater cone of depression on the planet, surpassing India and the US High Plains (Pei et al., 2015), and resulting in other ecological problems, including land subsidence, salt intrusion, and deep earth fissures (Cao et al., 2013).

Strategies to mitigate this severe groundwater depletion are therefore urgently needed. Some agronomic measurements are already being implemented in the traditional winter wheat-summer maize system across the NCP including, conservation agronomic practices (e.g., optimized planting dates and planting density (Meng et al., 2017)), and technologies (e.g., mulching (Qin et al., 2015; Wang et al., 2018a; Zhang et al., 2003; Zhu et al., 2018) and irrigation scheduling (Xu et al., 2018), drip or micro-sprinkler irrigation (Li et al., 2018; Liu et al., 2013), and drought-resistant crop varieties (Zhang et al., 2010)) to improve water use efficiency. While these agronomic measures have certainly reduced the rate of groundwater drawdown, their effects are currently insufficient to halt the decline.

An alternative strategy yet unassessed at the regional scale is crop diversification, that is, altering rotations to include fewer or different and more nutritious crops than the standard continuous wheat-maize rotation. The well-planned crop substitutions include incorporating variations in the number of harvests per year (e.g., incorporating a single harvest of spring maize into wheat-maize rotations) (Chen et al., 2015; Gao et al., 2015; Guo, Tao, Sheng, et al., 2013; Liu et al., 2008; Meng et al., 2012; Sun et al., 2011), the food crop species involved in rotations (dual maize cropping (Meng et al., 2012; Zhou, 2016), winter wheat-based double croppings (Liu \& Wang, 1994), and spring maize-based rotations (Wang, 2018b)), and the end use of the rotated crops (e.g., grain, cash, forage, or dedicated bioenergy) (Yang, Chen, Pacenka, Gao, Ma, et al., 2015; Yang et al., 2019). Combined with crop model, simulations have generally shown that alternative crop rotations can significantly reduce annual actual evapotranspiration $\left(E T_{a}\right)$ compared to the conventional wheat-maize system (e.g., APSIM Chen et al., 2010; Luo et al., 2018; Van Oort et al., 2016; Sun et al., ,2015; Sun et al., 

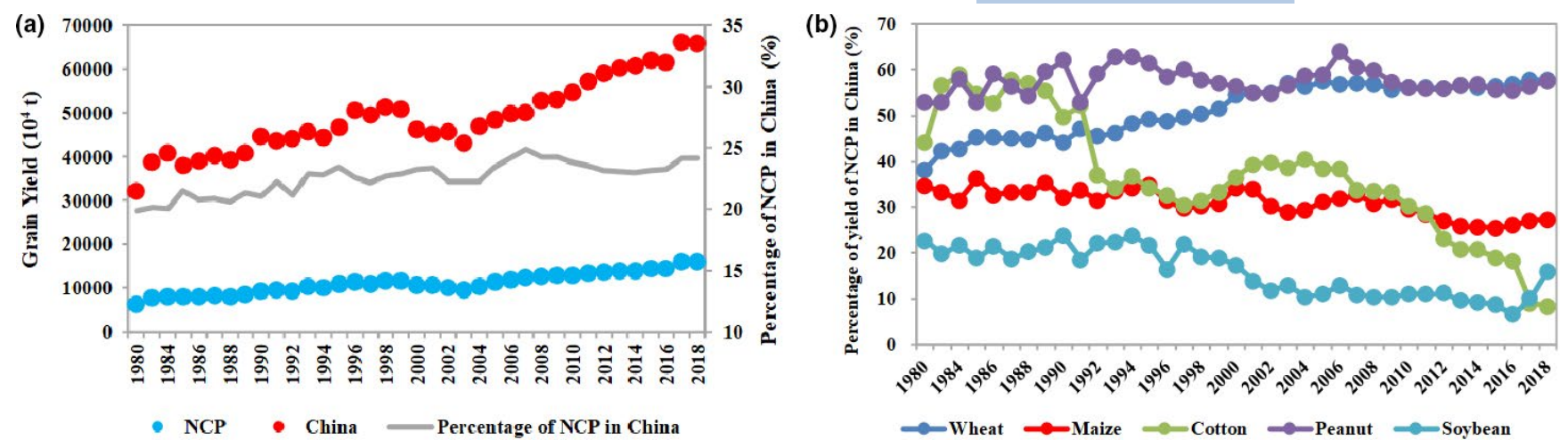

(c)

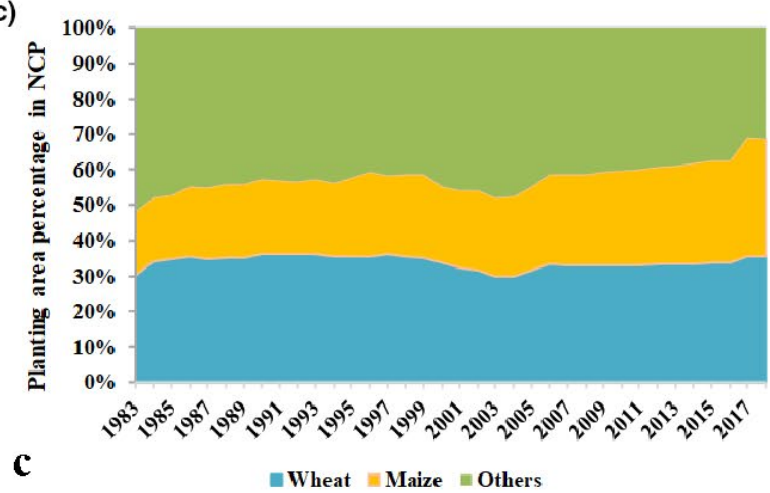

(e)

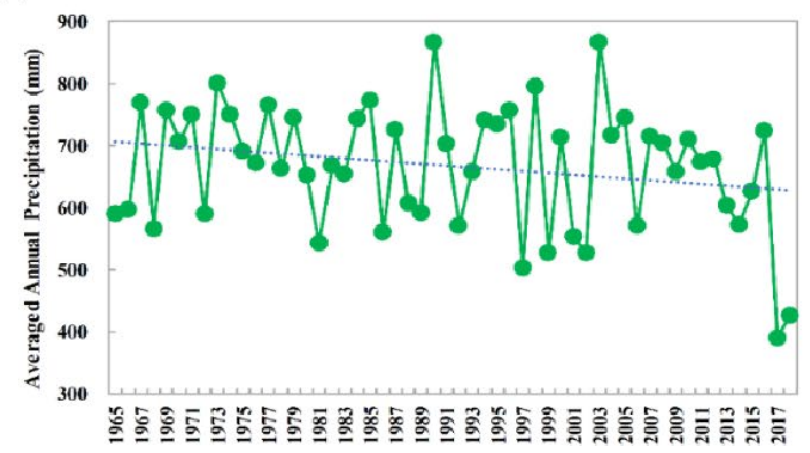

(d)

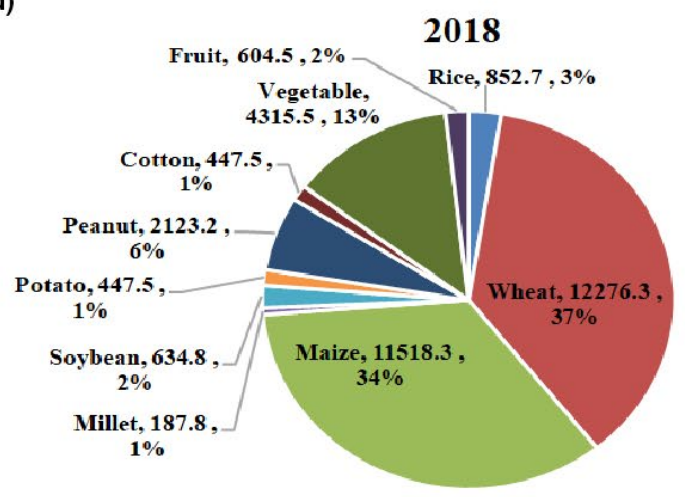

(f)

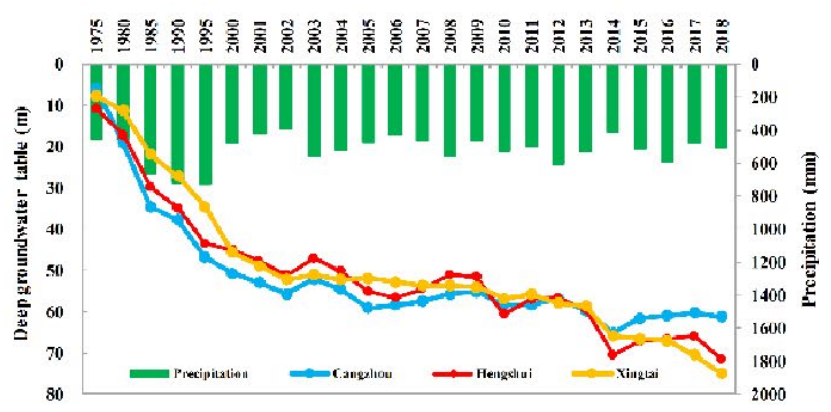

F I G U RE 1 Crop yield (a, b), planting area (c, d), and water resources (e, f) in the North China Plain over four decades

,2019; Xiao et al., 2017), WHCNS (Liang et al., 2019), and SWAP-WOFOST (Li \& Ren, 2019)). However, most of these studies have stopped short of exploring the consequences for sustainable groundwater use, with only a few of the studies reporting net groundwater use (i.e., recharge minus irrigation) (Kendy et al., 2003; Li \& Ren, 2019; Liang et al., 2019; Luo et al., 2018; Meng et al., 2012; Sun et al., 2011; Xiao et al., 2017; Zhang et al., 2004). Meanwhile, the potential benefits of alternative cropping systems for reversing groundwater depletion and achieving economic and food security co-benefits are also not broadly recognized and remain understudied.

To date, there has not been systematic evaluation synthesizing research on the relative effectiveness of diversified crop rotations on groundwater depletion and other sustainability challenges in the NCP. With the completion of numerous empirical studies on the relationship between diversified crop rotations and water use, there is a need to synthesize the findings to inform policy on options for improving sustainability. To address this knowledge gap, here, we use 30 years from 1990 to 2019 of empirical results to perform a detailed synthesis analysis to assess multiple outcomes of 31 diversified crop rotations tested in the NCP (Figure 2) and to compare their (a) water consumption $\left(E T_{a}\right)$, groundwater depletion or gain, and WUE (water use efficiency, $\mathrm{kg}$ of product per $\mathrm{m}^{3}$ of evapotranspiration water), (b) productivity (i.e., yield), and (c) economic output, all relative to the conventional winter wheat-summer maize system. By examining these multiple dimensions in parallel, we then examine whether certain alternative crop rotations offer multiple benefits in terms of water use, economic performance, and grain food security relative to current practices. The study provides essential information for utilizing crop rotations as an effective means to enhance the sustainability of food production across multiple outcomes and to minimize trade-offs. 


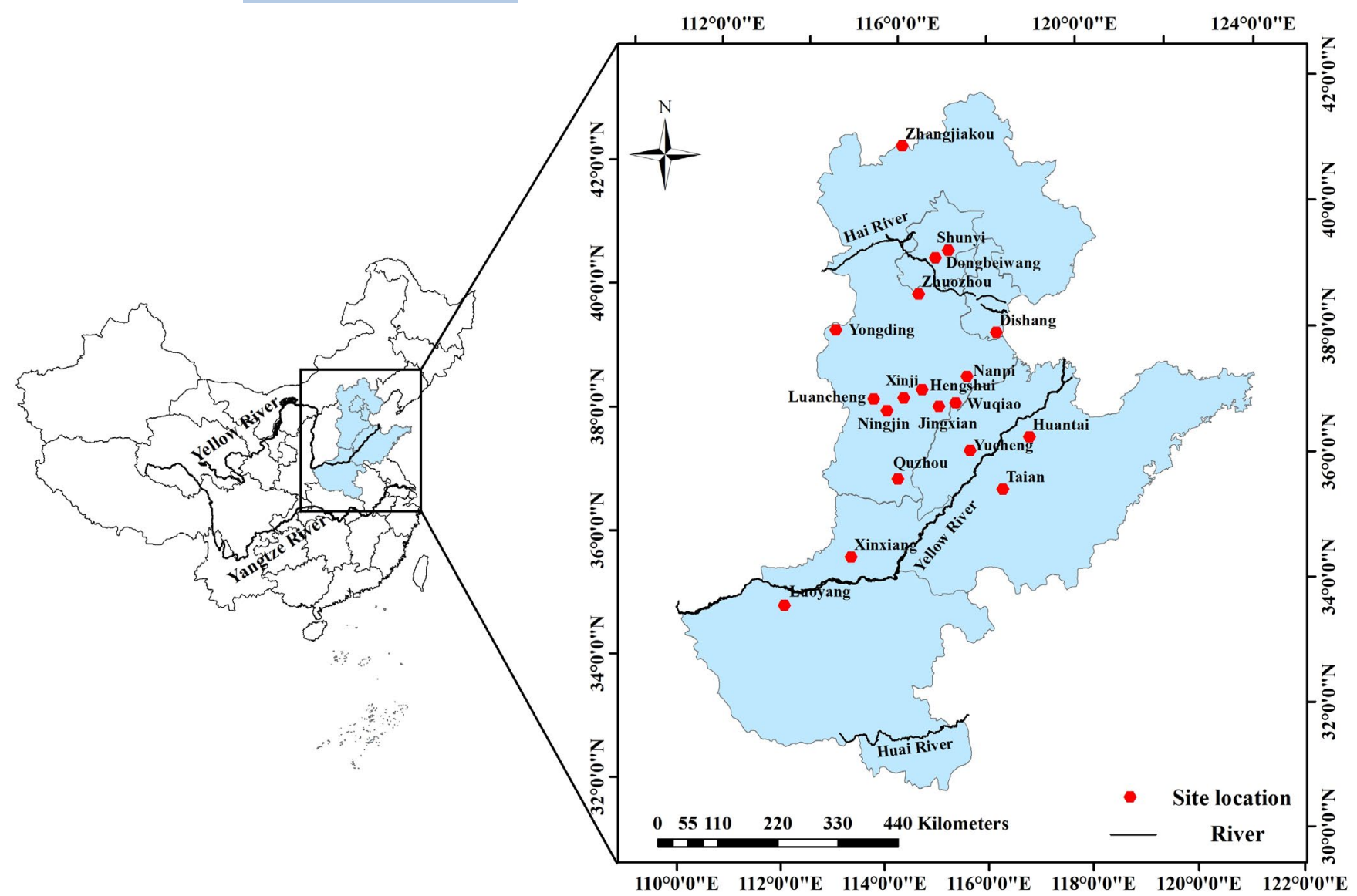

F I G U RE 2 Cropping system research sites in the North China Plain for the published reports used in this study

Search Topic: ("North China Plain" and "crop rotation" OR "Cropping

system")

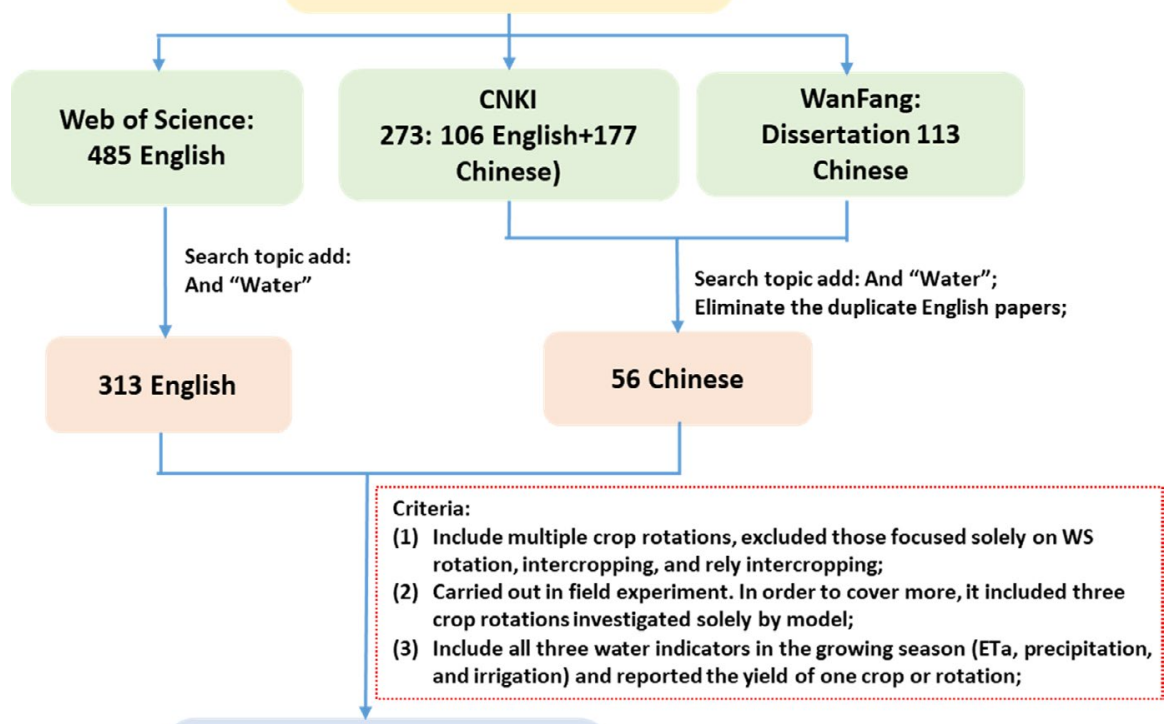

28 publications (15 English; 13 Chinese including 3 M.SC theses and 3 Ph.D. thesis)
F I G URE 3 Schematic representation of the literature database compilation process in this study 
F I G URE 4 Frequency of occurrence (data records) of 31 diversified crop rotations in the database (Cont: Continuous single cropping)

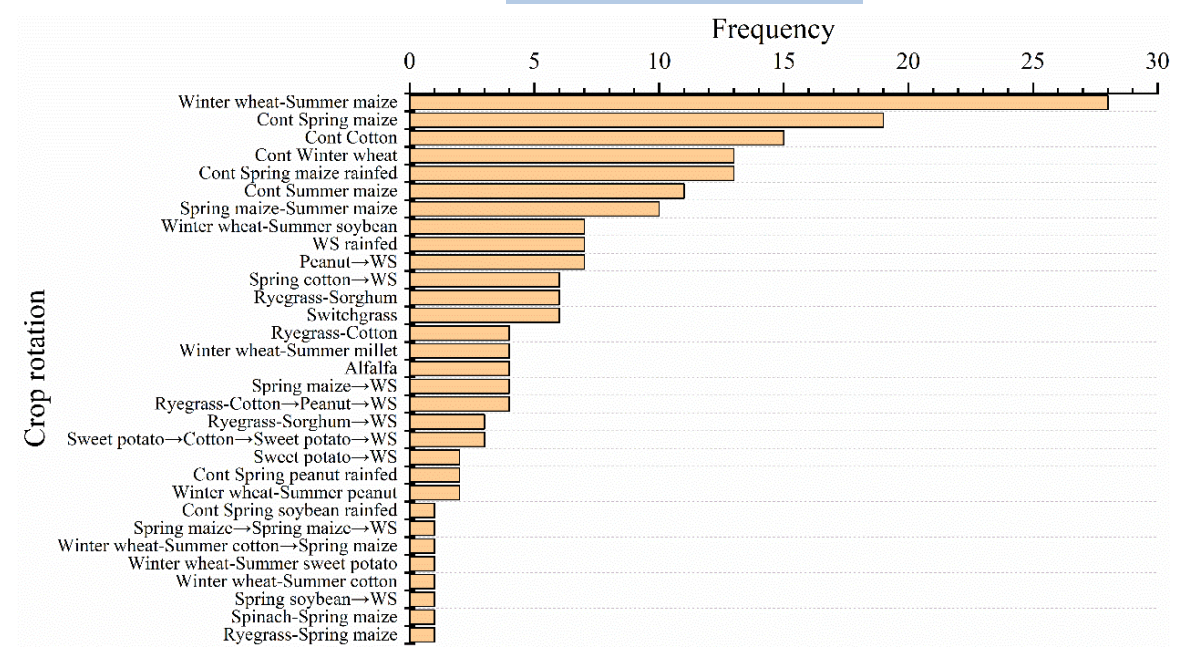

\section{2 | MATERIALS AND METHODS}

\section{1 | Data selection}

Publications related to 'research on water consumption of cropping system in the North China Plain' were intensively searched in four databases: CNKI (http://www.cnki.net/), WanFang DATABASE (http://g.wanfangdata.com.cn/index. html), Web of Science (http://apps.webofknowledge.com/), and the M.Sc. plus Ph.D. dissertation library in the China Agricultural University database. We used search terms including 'North China Plain' AND ('crop rotation*' OR 'cropping system*') AND ('water' OR 'water use efficiency' OR 'irrigation' OR 'groundwater use' OR 'evapotranspiration OR 'ET') in the article topic, title, abstract, or keywords. The databases were searched over the period between January 1970 and December 2019. The search yielded 871 publications including English and Chinese publications. All duplicates were removed. When different sources reported the same experimental results, the priority of inclusion was English paper $>$ Chinese paper $>$ Chinese Dissertation. For each crop rotation, a field experiment was considered superior to the validated modeling scenarios.

Studies were selected when they met the following criteria (Figure 3):

1. Studies included data that focused on diversified crop rotations, including diversified multiple cropping systems (more than one harvest per year on average, the rotation cycle is more than 1), and mono-cropping (same single crop year after year, with one harvest per year, the rotation cycle year is one), and included a control case of the conventional winter wheat-summer maize (WS) double cropping system in the same publication. Publications focusing solely on the WS rotation, intercropping, or relay intercropping were excluded.

2. The crop rotations were carried out in the field experiments. In order to cover a greater number of potentially feasible crop rotations, we also included three crop rotations investigated using modeling, such as continuous summer maize cropping system (Sun et al., 2019; Van Oort et al., 2016; Xiao et al., 2017; Zhao et al., 2018), spring maize $\rightarrow$ spring maize $\rightarrow$ WS with four harvests in 3 years (Luo et al., 2018), and winter wheat-summer millet double cropping system (Sun et al., 2014).

3. The study needed to contain all three main water indicators in the growing season, viz. ET (Actual evapotranspiration; not the crop potential evapotranspiration $E T_{o}$ calculated by Penman-Monteith formula), precipitation, and irrigation. In addition, they needed to report the yield of each crop. Values of the required quantities can be shown by each crop within the crop rotation, or as totals or averages over the whole crop rotation.

The data were extracted from tables or figures using GetData software (http://getdata-graph-digitizer.com/). After reading and filtering, 15 English publications and 13 Chinese papers, including $3 \mathrm{MSc}$ theses and $3 \mathrm{PhD}$ thesis, remained. Finally, we compiled 421 data records about 31 crop rotations from 28 references to compare the water consumption, inferred groundwater table change, crop yield, economic output, and water use efficiency of diversified crop rotations. Frequency of occurrence (data records) of 31 diversified crop rotations in the database is shown in Figure 4. This database covers all crop rotations which were attempted in research within the North China Plain during the past 30 years in field experiments or in validated crop models and for which the required quantities were reported in the publications.

The final database spanned 31 diversified cropping systems (detailed in Table S1): the conventional WS rotation with irrigation and rainfed treatments, six monocultures with both irrigation and rainfed treatments, two perennial crops (alfalfa and switchgrass with irrigation), ten double cropping systems with two harvests per year, six rotations comprising wheat-maize double cropping in one of the years, alternating with a year with one harvest (i.e., with three harvests in 
2 years), and five multi-year cropping systems with rotation cycles longer than 2 years. The geographic region and locations where research data were collected and the corresponding literature are shown in Figure 2.

The dataset included the following variables: publication author and year, experiment site information (longitude, latitude, altitude, annual mean temperature, annual precipitation, soil texture, $0-20 \mathrm{~cm}$ soil organic matter, $\mathrm{pH}$, total $\mathrm{N}$, available $\mathrm{N}$, available Olsen-P, available $\mathrm{K}$ and bulk density), crop rotation, rotation cycle year, cropping index, crop name(s), experimental year, water indicators in crop growing season ( $E T_{a}$, recharge, irrigation, and precipitation), crop yields, grain yields, biomass, price, economic output, water use efficiency (WUE), and economic WUE (Yuan $\mathrm{m}^{-3}$ of evapotranspiration).

In the whole analysis process as well as the underlying studies, the traditional irrigated WS rotation plays the role of a control (or reference) relative to the other 30 crop rotations. This does not presuppose a judgment about irrigated WS rotation, but merely reflects the role of irrigated WS rotation as the region's dominant cropping system for decades.

Meteorological data, including precipitation, were obtained from the China meteorological data sharing service system (National Meteorological Information Centre, 2019) and http://www.nmic.cn/ (Figure 1e and Figure S4). Water resources data for both surface water and groundwater (Figure S7) were obtained from the annual China Water Resources Bulletin (China Water Resources Bulletin, 2019). Annual crop yield (Figures S1 and S2) and crop planting area (Figure S1 and S3) data came from the China Rural Statistical Yearbook (National Bureau of Statistics of China, 2019b).

\subsection{Calculations}

\subsection{1 | Actual evapotranspiration $\left(E T_{a}\right)$}

Total actual evapotranspiration $\left(E T_{a}\right)$ during the growing season of each crop was calculated using the soil water balance model and the following equation:

$$
E T_{a}=P+I+\mathrm{SWD}-D-R+\mathrm{CR}
$$

where $E T_{a}$ is actual evapotranspiration ( $\mathrm{mm} /$ growing season) of each crop, $P$ is precipitation ( $\mathrm{mm} /$ growing season), $I$ is irrigation ( $\mathrm{mm} /$ growing season), SWD is soil moisture storage at sowing date minus the value at harvest to a depth of $2 \mathrm{~m}$ in the soil profile, $D$ is deep percolation ( $\mathrm{mm} /$ growing season), $R$ is runoff, and CR is capillary rise to the root zone. $R$ is considered negligible due to the study region's flatness, and CR is considered negligible in the region because the groundwater table is more than $30 \mathrm{~m}$ below the surface and soil water extraction will not occur below $2 \mathrm{~m}$.

\subsubsection{Groundwater table decline inferred from net water use}

We defined net groundwater depletion of each crop [NWD (mm/yr)] (Yang, Chen, Pacenka, Gao, Ma, et al., 2015; Yang et al., 2019) as follows:

$$
\mathrm{NWD}=D-I
$$

where negative values of NWD indicate groundwater depletion (decreased storage in the aquifer) and positive values indicate increased aquifer storage. $I$ is irrigation $(\mathrm{mm} / \mathrm{yr}) . D$ is deep percolation ( $\mathrm{mm} /$ year), which is the original reported value in the literature. A few reports did not provide deep percolation data; in these cases, deep percolation was approximated as follows:

$$
D=\alpha \times(P+I)
$$

where $D$ is deep percolation (mm), $P$ is precipitation (mm), including the growing season and fallow period. If $P \leq 90 \mathrm{~mm}$, then $\alpha$ is 0.1 , if $90 \mathrm{~mm}<P<250 \mathrm{~mm}$, then $\alpha$ is 0.15 , and if $p \geq 250 \mathrm{~mm}$ then $\alpha$ is 0.2 (Sun et al., 2006). When $D$ is recalculated using Equation 3, $E T_{a}$ was deducted from $D$.

Recharge of the groundwater table each year can be calculated from the percolation rate at $200 \mathrm{~cm}$. The lag time to reach the groundwater table and the lateral movement of groundwater were not considered for the broad geographic area having uneven depletion. The net groundwater amount of each crop rotation was converted into groundwater table change $(\Delta h)$, using the following equation:

$$
\Delta h=\frac{\mathrm{NWD}}{\mu}
$$

where $\Delta h$ is groundwater table change ( $\mathrm{m}_{\text {year }}{ }^{-1}$ ) during a cropping system, and NWD is net water depletion of the cropping system $\left(\mathrm{mm} \mathrm{year}^{-1}\right.$ ), which was calculated as recharge by deep percolation minus the amount of groundwater used for irrigation. $\mu$ is the specific yield set to 0.2 (Yang, Chen, Pacenka, Gao, Zhang, et al., 2015; Yang et al., 2019).

\subsubsection{Economic output, WUE, and EWUE}

A realistic consideration of yield accounts for the differences in economic values between crop species. The economic output of each crop is expressed as within-year yield multiplied by the corresponding product price in inflationadjusted Yuan minus costs. To eliminate inflation or deflation as a source of variability between the different cases in different years, we used the China National Consumer Price Index (CPI) to adjust crop prices and economic outputs 
covering all database years. Once adjusted, the economic output values became less dependent on year-by-year fluctuations in prices of inputs and yields. Since the database in this study started in 1992, we adopted the 1990 CPI as the baseline; thus, our economic values are expressed in 1990 Yuan. All CPI values from 1990 to 2018, sourced from the China Statistical Yearbook (National Bureau of Statistics of China, 2019a), are in Table S2. Crop prices were sourced from the China Yearbook of Agricultural Price Survey (Table S3).

Water use efficiency (WUE, $\mathrm{kg}$ of product per $\mathrm{m}^{3}$ of evapotranspiration water) is the ratio of yield to $E T_{a}$. EWUE builds on WUE by including the economic output per $\mathrm{m}^{3}$ of evapotranspiration.

The economic output, WUE, and EWUE were calculated as follows:

$$
\begin{gathered}
\text { Economic Output }_{i}=\text { Yield }_{i} \times \text { Price }_{i} \times \frac{\mathrm{CPI}_{i}}{\mathrm{CPI}_{1990}} \\
\text { WUE }=\frac{\sum_{1}^{n} \text { Yield }}{\sum_{1}^{n} \mathrm{ET}_{a}} \\
\text { EWUE }=\frac{\sum_{1}^{n} \text { Economic Output }_{1}^{n} \mathrm{ET}_{a}}{\sum_{1}}
\end{gathered}
$$

where economic output is the crop within-year yield multiplied by its corresponding price for the indicated year minus crop production costs (Yuan ha ${ }^{-1}$ ), $i$ is one given year, CPI is the national Consumer Price Index, WUE is yield water use efficiency $\left(\mathrm{kg} \mathrm{m}^{-3}\right)$ of one crop rotation in one rotation cycle, $E T_{a}$ is actual evapotranspiration ( $\mathrm{mm}$ ) of one crop in the growing season, Yield denotes economic yield of one crop $\left(\mathrm{kg} \mathrm{ha}^{-1}\right), n$ is the sequence number of the crop in one crop rotation, and EWUE is economic output water use efficiency (Yuan $\mathrm{m}^{-3}$ ) of one crop rotation in one rotation cycle. For comparison: $1 \mathrm{USD}=7.08$ Yuan in June 2020. Crop prices for economic yield and cost taken from the literature when included. When not included, values from the China Yearbook of Agriculture Price Survey for crop type in the corresponding year were used. In both cases, the specific year price was adjusted for inflation using the ratio of CPI values for reference year and project year.

\subsection{4 | Cropping index}

The cropping index (CI) is defined as the number of crop harvests per year within a cropping system cycle, which is calculated as follows:

$$
\mathrm{CI}=\frac{\text { Crop Harvests }}{\text { Rotation Years }}
$$

where Crop Harvests is the number of crop harvests within a complete crop rotation cycle, and Rotation Years is the number of years in that cropping system cycle. For example, the CI of the winter wheat-summer maize double cropping system is 2 (2 crop harvests/1 rotation year).

\section{3 | Statistical analysis}

Linear regression with mixed-effects models (Zuur et al., 2009) (function lme in R package nlme) was used to estimate the average values of yield, WUE, economic output, and EWUE and compare differences in these parameters in diversified crop rotations. We used publications and experiments within publications as random effects to account for differences among the studies (publications) and the experiments (sites $\times$ years) within studies. The associations among water indicators (groundwater table decline, ET, irrigation, recharge, precipitation) and economic output, EWUE, crop diversity, cropping index, growing days, fallow days, and with or without rainfed, species combinations with and without wheat or maize were visualized using principal component analysis (PCA), using the vegan package in $R$ (Oksanen et al., 2017; R Core Team, 2014). Principal component 1 (PC1) is mainly associated with cropping intensity, characterized by cropping index (average number of harvests per year), cropping days/year, fallow days/year, ET, irrigation amount/year, and ground water decline. Economic output has a high association with these "intensity" variables. Cropping systems with wheat are characterized by high water use, groundwater table decline, and high economic output. Principal component 2 (PC2) is associated with the presence of maize and with economic water use efficiency. Cropping systems with more maize tend to have higher economic water use efficiency and crop diversity as well as positive economic output in an absolute sense. The correlation matrix of these indicators was calculated and visualized using the Performance Analytics package in $R(\mathrm{R}$ Core Team, 2014).

\section{3 | RESULTS}

\section{1 | Water consumption $\left(E T_{a}\right)$ of diversified crop rotations}

The conventional wheat-maize (WS) double cropping system had an average annual $E T_{a}$ during the growing season of $733 \mathrm{~mm}$ across all years, crops, and sites (Figure 5 , Table S1). Seven crop alternative rotations had equal or greater $E T_{a}$ than the conventional WS. All of which, including WS, had intensive double cropping each year without fallow periods. A ryegrass-sorghum rotation for 


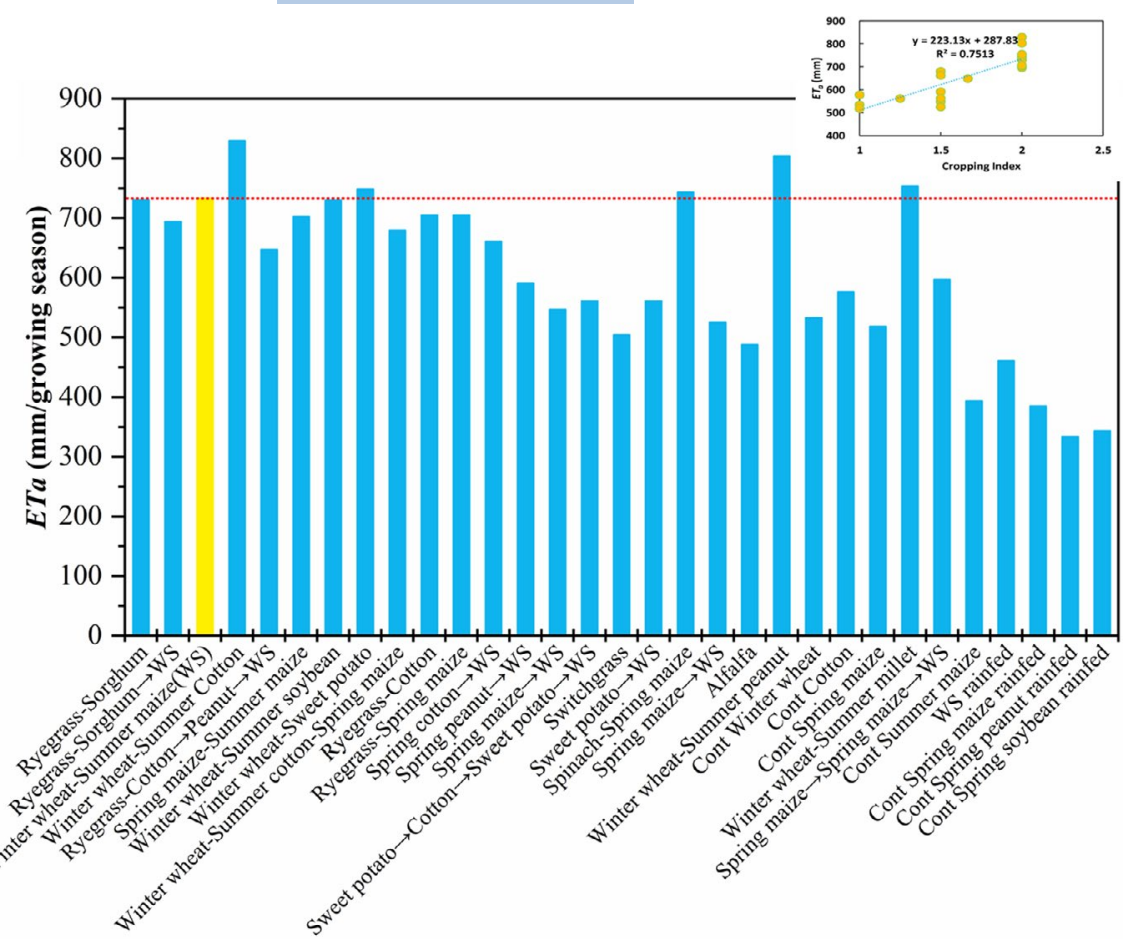

F I G URE 5 Annual averaged evapotranspiration $\left(E T_{a}\right)$ during the growing season of diversified crop rotations in the North China Plain. WS: winter wheatsummer maize rotation. Cont: continuous cropping. Red line is a baseline $E T_{a}$ for the WS rotation livestock forage produced more aboveground biomass than WS in a 6-year field experiment (Yang et al., 2019), at similar $E T_{a}(730 \mathrm{~mm})$ and similar irrigation $(375 \mathrm{~mm})$, with $416 \mathrm{~mm}$ rainfall (Table S1). Five winter wheat-based double-crop rotations (Liu \& Wang, 1994; Sun et al., 2014; Wang, 2011) had equal or greater $E T_{a}(730-823 \mathrm{~mm})$ than the conventional WS. One spring maize-based rotation (spinach-spring maize) had an average $E T_{a}$ of $743 \mathrm{~mm}$ in a 3-year field experiment (Wang, 2018b) (Figure 5). Table $\mathrm{S} 1$ details the irrigation and rainfall information of all tested crop rotations.

Single cropping (rainfed or irrigated) and perennial crops had $E T_{a}$ values $21 \%-54 \%$ below that of WS. Three rainfed continuous cropping systems with a cropping index of one had $E T_{a}$ values $<400 \mathrm{~mm}$, half that of conventional WS: spring maize (Chen et al., 2015; Guo et al., 2013; Yan et al., 2016), spring peanut, and spring soybean (Liu \& Wang, 1994) (Figure 5). The $E T_{a}$ of a rainfed WS in a 7-year field experiment was $460 \mathrm{~mm}$ (Chen et al., 2015). The $E T_{a}$ of perennial crops and single continuous cropping systems based on one crop per year under irrigation were all $<600 \mathrm{~mm}$. The $E T_{a}$ of perennial crops - alfalfa for livestock (Liu \& Wang, 1994; Sun et al., 2014) and switchgrass for bioenergy (Yun et al., 2019)—were $488 \mathrm{~mm}$ and $504 \mathrm{~mm}$, respectively. The $E T_{a}$ of single continuous cropping with irrigation, including winter wheat, cotton, or spring maize, ranged from 518 $576 \mathrm{~mm}$. Thus, reduction in $E T_{a}$ can be achieved by recuing water input with irrigation and decreasing cropping index.

The multiple WS-based rotations (sweet potato $\rightarrow$ cotton $\rightarrow$ sweet potato $\rightarrow$ WS with five harvests in 4 years, and ryegrass-cotton $\rightarrow$ peanut $\rightarrow$ WS with five harvests in 3 years, both over a 12-year field experiment (Yang, Chen, Pacenka, Gao, Ma, et al., 2015), and modeled spring maize $\rightarrow$ spring maize $\rightarrow$ WS (Luo et al., 2018)) had $E T_{a} 12 \%-23 \%$ below that of WS. Five WS-based rotations with three harvests in 2 years had $E T_{a} 10 \%-28 \%$ below WS (Figure 5). The grainbased rotation of spring maize $\rightarrow$ WS, which has received much attention in the last decade, had an average $E T_{a}$ of $547 \mathrm{~mm}$ across three experimental stations in Luancheng, Quzhou, and Wuqiao (Guo, Tao, Wang, et al., 2013; Meng et al., 2012; Wang, 2011).

The intensive double cropping systems (ryegrass-spring maize, ryegrass-cotton, ryegrass-sorghum $\rightarrow \mathrm{WS}$, and spring maize-summer maize dual cropping) had similar $E T_{a}$ values to WS, ranging from 694-705 mm (Figure 5).

In summary, $77 \%$ of diversified crop rotations had an average growing season $E T_{a}$ lower than the conventional wheat-maize double cropping system (Figure 5). Singlespecies continuous cropping systems with one harvest per year saw reductions in $E T_{a}$ between $21 \%-54 \%$. The multiple wheat-maize-based rotations with rotation cycles greater than 2 years also experienced reductions in $E T_{a}$ between 10 28\% (see Table S1 and Figure S6). However, rotation systems that maintained a double cropping strategy each year with or without winter wheat did not reduce $E T_{a}$. The negative correlation between cropping index (harvest numbers/rotation year) and $E T_{a}$ implies that introducing a fallow period each year into intensive wheat-maize double cropping system in NCP reduces actual water consumption by $10 \%-54 \%$ (see Figure 5 inset). 
F I G URE 6 Annual average groundwater table change with irrigation plus rainfall in diversified crop rotations in the North China Plain. WS is winter wheatsummer maize rotation. Cont is single continuous cropping

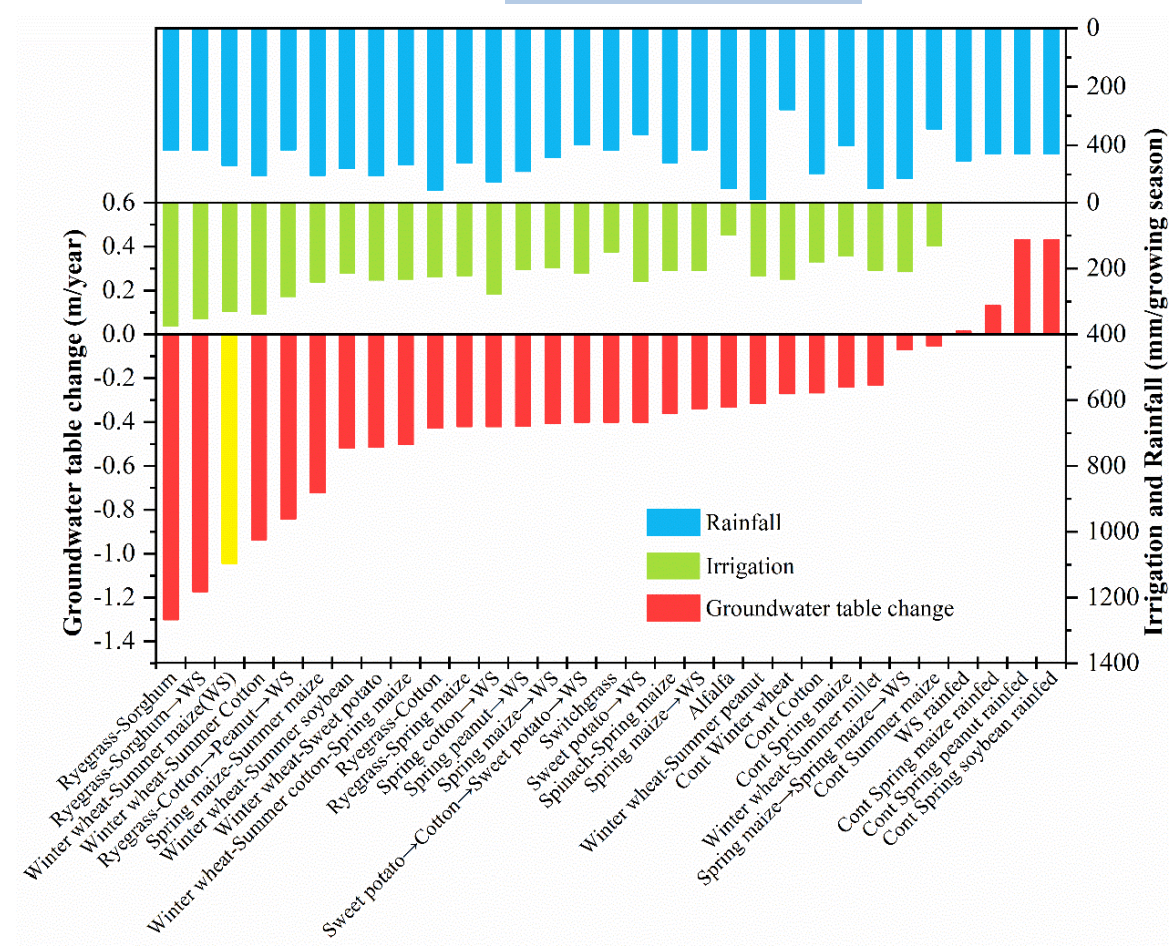

\section{2 $\quad$ Effect of diversified crop rotations on the groundwater table}

The annual groundwater table change of 31 crop rotations ranged from +0.43 to $-1.3 \mathrm{~m} \mathrm{year}^{-1}$ (Figure 6). The vast majority (almost 90\%) of these rotations led to reductions in groundwater table decline, compared to that of the conventional wheat-maize system $\left(-1.04 \mathrm{~m}\right.$ year $\left.^{-1}\right)$. Three single-species continuous cropping systems (rainfed) with one harvest per year caused the groundwater table to rise by +0.13 to $+0.43 \mathrm{~m} \mathrm{year}^{-1}$. Roughly half of the 31 crop rotations reduced the groundwater table decline rate by $50 \%$, achieving -0.31 to $-0.52 \mathrm{~m}$ year $^{-1}$, against the conventional wheat-maize (Figure 6, Figure S7).

The rainfed winter wheat-summer maize rotation in Figure 6 showed a neutral groundwater table change, as reported in a 7-year field experiment at Luancheng (averaging $454 \mathrm{~mm}$ annual rainfall) (Chen et al., 2015). An APSIM simulation of rainfed wheat-maize using 1982-2013 meteorological data yielded a groundwater increase of $+0.05 \mathrm{~m} \mathrm{year}^{-1}$ (Sun et al., 2019). In another APSIM study, a rainfed wheat-maize double cropping continuous cultivation system with $50 \%$ and 100\% plastic film mulching between 1961 and 2011 in Hebei Province simulated a groundwater table rise of +0.30 to $+0.40 \mathrm{~m}$ year $^{-1}$ (Van Oort et al., 2016). However, the rainfed wheat-maize yielded $44 \%$ less grain than irrigated WS (Van Oort et al., 2016). Simulated single continuous summer maize (Sun et al., 2014; Xiao et al., 2017) and spring maize $\rightarrow$ spring maize $\rightarrow$ wheat-maize rotation (Luo et al., 2018) with $580 \mathrm{~mm}$ rainfall and normal irrigation resulted in a negligible groundwater table change of -0.05 to $-0.07 \mathrm{~m}$ year $^{-1}$.
Conventional wheat-maize with $470 \mathrm{~mm}$ rainfall and $330 \mathrm{~mm}$ irrigation had an average groundwater table decline of $-1.04 \mathrm{~m} \mathrm{year}^{-1}$ (Figure 6) - this value was obtained by combining our 12-year field experiment (Yang, Chen, Pacenka, Gao, Ma, et al., 2015) with 3 years in Luancheng (Qin et al., 2018), 2 years in Wuqiao (Gao et al., 2015), and 2 years in Quzhou (Sun et al., 2011) — which is similar to modeling results of -1.13 to -1.60 m year $^{-1}$ over various period (Chen et al., 2010; Kendy et al., 2004; Sun et al., 2019; Van Oort et al., 2016; Xiao et al., 2017).

Three single continuous cropping systems - spring maize, spring peanut, and spring soybean-with precipitation of $430 \mathrm{~mm}$ per growing season-caused the groundwater table to rise. Three other single continuous cropping systemswinter wheat, cotton, and spring maize (all irrigated)—had groundwater table change of -0.23 to $-0.27 \mathrm{~m} \mathrm{year}^{-1}$, or at least $76 \%$ better than conventional wheat-maize (Figure 6).

Given NCP's abundant $4500-5300^{\circ} \mathrm{C}$ days of accumulated growing season temperatures, intensive double cropping of wheat-maize has dominated this area over the past 40 years, with its higher grain production for food security, but at the expense of groundwater (Liu \& Chen, 2005). While single cropping systems per year mitigate groundwater table decline, they do not capitalize on the region's ample light and heat resources for crop production (Liu \& Chen, 2005). Thus, water-saving crop rotations with a cropping index between 1.25 and 2 should be favored for sustainable groundwater use (Figure S7). The introduction of more profitable crops and a fallow period into the conventional wheat-maize rotation offers a trade-off for groundwater and grain security. 


\subsection{Yield, economic output, and water use efficiencies of diversified crop rotations}

\subsection{1 | Grain-based crop rotations}

Annual grain yields and WUE values (Figure 7a), and annual economic output (inflation-adjusted Yuan $\mathrm{ha}^{-1}$ ), and economic water use efficiency (EWUE) (Yuan $\mathrm{m}^{-3}$ of evapotranspiration) (Figure 7b) of eight grain-based rotations provide useful insights to crop output. The annual grain yield and WUE of conventional winter wheat-summer maize rotation were $14.1 \mathrm{t} \mathrm{ha}^{-1}$ and $1.95 \mathrm{~kg} \mathrm{~m}^{-3}$, with annual economic output and EWUE of $8.0 \times 10^{3} \mathrm{Yuan} \mathrm{ha}^{-1}$ and $1.13 \mathrm{Yuan} \mathrm{m}^{-3}$ (Figure 7a,b).

Only the spring maize-summer maize dual rotation per year produced higher annual grain yields (15.9 $\mathrm{t} \mathrm{ha}^{-1}, 12 \%$ more) than conventional wheat-maize $(p>0.05)$ (Table S4) because spring maize produced $50 \%$ more grain yield than winter wheat (Meng et al., 2017; Zhou, 2016). The higher photosynthesis and stomatal resistance of spring maize $(\mathrm{C} 4$ crop) than winter wheat (C3 crop) ensure higher use efficiencies of light, water, and nitrogen (Sun et al., 2019). The spring maize-summer maize rotation had $24 \%$ higher WUE than conventional wheat-maize (Figure 7a). Winter wheat needs $225 \mathrm{~mm}$ irrigation during the dry growing season which is $33 \%$ more than spring maize.

Meanwhile, the spring maize-summer maize rotation had $27 \%$ significantly higher economic output $(p<0.05)$ and $38 \%$ higher EWUE than conventional wheat-maize. The water needs of spring maize and summer maize almost matched the growing season rainfall in this region, saving $\sim 75 \mathrm{~mm}$ of irrigation over winter wheat in winter wheat-summer maize rotation and decreasing seasonal $E T_{a}$. Although the dual maize rotation performed better than winter wheat-summer maize for yield and economic output, the need for sufficient heat resources, suitable varieties, and matched harvest times limit its adaptability and generalization in much of the NCP.

The spring maize $\rightarrow$ winter wheat-summer maize rotation (three harvests in 2 years) produced $25 \%$ lower grain yields $\left(10.6 \mathrm{t} \mathrm{ha}^{-1}\right)$ and $16 \%$ lower annual economic output than conventional wheat-maize $(p<0.05)$. Despite a $25 \%$ reduction in grain yield and $16 \%$ reduction in economic output due to reduced planting frequency of winter wheat once every 2 years, the spring maize $\rightarrow$ winter wheat-summer maize rotation had similar WUE and EWUE to conventional WS, reducing $E T_{a}$ by $20 \%$ (Figure 5 ) and mitigating $61 \%$ of groundwater table decline (Figure 6).

The other five grain-based cropping systems-WS rainfed, spring maize rainfed, and three single continuous croppings of spring maize, summer maize, and winter wheat-had $36 \%-57 \%$ lower yields and 44\%-63\% lower economic outputs than conventional wheat-maize $(p<0.05)$, with no significant differences in WUE and EWUE (Table S4). WS rainfed saved $\sim 300 \mathrm{~mm}$ of irrigation water but produced $40 \%$ lower grain yield, 54\% lower economic output and $7 \%$ lower WUE, and 34\% lower EWUE than wheat-maize with irrigation at 300-330 mm year ${ }^{-1}(p<0.05)$ (Guo, Tao, Wang, et al., 2013; Sun et al., 2011; Yang, Chen, Pacenka, Gao, Ma, et al., 2015; Yang et al., 2019). Continuous winter wheat had the lowest yield, economic output, and WUE, followed by continuous spring maize rainfed, WS rainfed, and continuous summer maize. Continuous summer maize had $8 \%$ higher WUE and similar EWUE compared to wheatmaize (Figure 7a,b).

Single cropping systems performed better than conventional winter wheat-summer maize for mitigating groundwater table decline, but soil water evaporates unproductively and agriculturally favored light and heat resources are wasted during a long fallow period each year. Single cropping systems produced 36\%-70\% lower net economic outputs per year than conventional wheat-maize.

\subsection{2 | Other diversified crop rotations}

The full set of 31 diversified crop rotations included crops from different families and genera, with different production objectives and value chains. Because the yields and derived WUE of 23 of these crop combinations were not comparable to strictly grain-based rotations, these dimensions were not assessed for all rotations. On the other hand, economic output and EWUE could be expressed for all rotations (Figure 8).

Half of the diversified crop rotations had higher annual averaged economic outputs than conventional wheat-maize $\left(8.0 \times 10^{3}\right.$ Yuan ha $\left.{ }^{-1}\right)$. The sweet potato $\rightarrow$ cotton $\rightarrow$ sweet potato $\rightarrow$ wheat-maize rotation, with five harvests in 4 years, had the highest economic output $\left(19.5 \times 10^{3}\right.$ Yuan $\left.^{-1}\right)$ and EWUE (4.22 Yuan $\mathrm{m}^{-3}$ ), being 1.4 and 2.7 times significantly higher, respectively, than WS $(p<0.05)$ (Table S5). The spinach-spring maize, ryegrass-cotton, and ryegrasscotton $\rightarrow$ peanut $\rightarrow$ WS rotations produced $58 \%-77 \%$ higher economic outputs than wheat-maize. Spinach (an edible vegetable) and cotton (cash crop), both have higher prices and economic outputs than winter wheat and maize, which contributed strongly to the economic output of their rotations (Wang et al., 2018a; Yang, Chen, Pacenka, Gao, Ma, et al., 2015). The EWUEs of the above crop rotations were at least $69 \%$ higher than wheat-maize.

The spring peanut $\rightarrow$ winter wheat-summer maize rotation, continuous cotton, and spring cotton $\rightarrow$ wheat-maize rotation had $21 \%-31 \%$ higher economic outputs, due to the higher prices for peanut and cotton (Yang, Chen, Pacenka, Gao, Ma, et al., 2015), and 52\%-89\% higher EWUE than wheat-maize. Two sorghum-containing rotations (ryegrasssorghum $\rightarrow$ WS and ryegrass-sorghum rotations) surpassed the economic output of WS by $11 \%-19 \%$ because sorghum 
F IGURE 7 Annual grain yield and water use efficiency (WUE) (a) and annual economic output and economic water use efficiency (EWUE) (b) of eight grain-based crop rotations in the North China Plain.

Black error bars on green bars and red error bars on yellow dots are standard deviations for yield and WUE, respectively. Orange error bars on blue bars and black error bars on red dots are standard deviations for economic output and EWUE, respectively. 'WS': winter wheat-summer maize rotation. 1USD $=7.0805$ Yuan in June 2020. The economic output values are expressed in 1990 Yuan due to adopting the 1990 CPI as the baseline
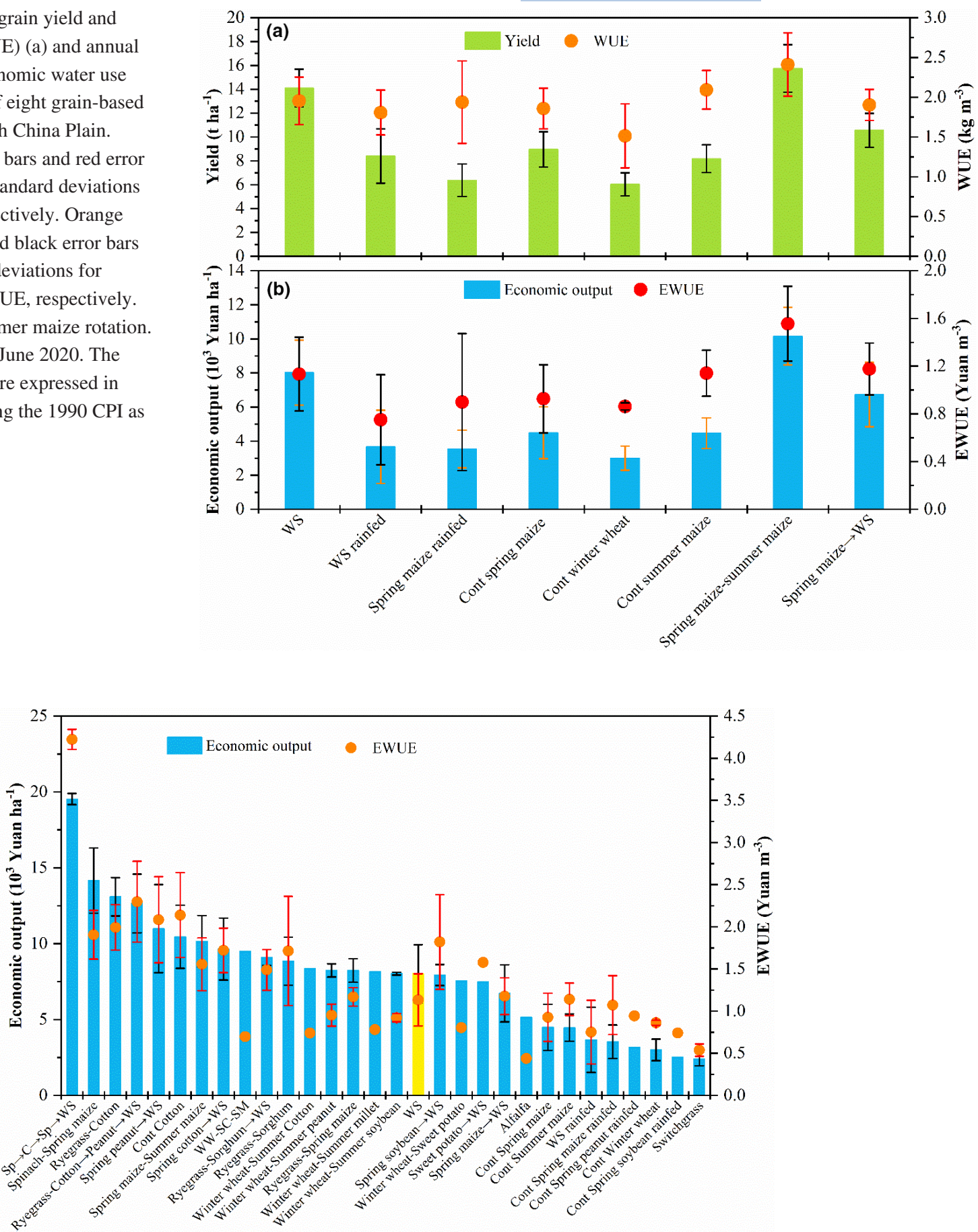

F I G U RE 8 Annual economic output and economic water use efficiency (EWUE) of 31 diversified crop rotations in the North China Plain. 'Sp $\rightarrow \mathrm{C} \rightarrow \mathrm{Sp} \rightarrow$ WS': sweet potato $\rightarrow$ cotton $\rightarrow$ sweet potato $\rightarrow$ winter wheat-summer maize; 'WW-SC $\rightarrow$ SM': winter wheat-summer cotton $\rightarrow$ spring maize; 'WS': winter wheat-summer maize. Symbol '-' in cropping systems: two crops within 1 year; Symbol ' $\rightarrow$ ': two crops across 2 years. Black error bars on green bars and red error bars on yellow dots represent one standard deviation for economic output or EWUE. Absence of an error bar indicates that the crop rotation was not replicated in the database. 1USD = 7.0805 Yuan in June 2020. The economic output values are expressed in 1990 Yuan due to adopting the 1990 CPI as the baseline

(bioenergy crop) was harvested for its entire aboveground biomass $\left(44.6 \mathrm{t} \mathrm{ha}^{-1}\right)$, aiding the $32 \%-52 \%$ higher EWUE than winter wheat-summer maize.

Thewinterwheat-baseddoublecropping systems peryearwith summer cotton, peanut, soybean, or sweet potato-had similar economic outputs $\left(7.6-8.4 \times 10^{3}\right.$ Yuan $\left.^{-1}{ }^{-1}\right)$ to wheatmaize but 16\%-35\% lower EWUE values due to their higher water use. This demonstrates that retaining winter wheat in a double-crop rotation each year in the NCP does not balance economic outputs with groundwater sustainability. In 
contrast, the wheat-maize-based multiple crop rotations with three harvests in 2 years (spring soybean $\rightarrow$ wheat-maize rotation and sweet potato $\rightarrow$ wheat-maize rotation) had similar economic outputs $\left(7.5-7.9 \times 10^{3}\right.$ Yuan $\left.^{-1}\right)$ to WS, but $40 \%-61 \%$ higher EWUE. The ryegrass-spring maize double rotation had a similar economic output and EWUE to wheat-maize.

Alternative rotations with perennial crops (i.e., alfalfa and switchgrass) or with a single continuous rainfed crop (i.e., spring peanut and spring soybean) had 36\%-70\% lower annual economic outputs and 17\%-61\% lower EWUE than the conventional wheat-maize system, indicating that these rotations are likely not good candidates for future diversified systems.

In summary, 16 of the 31 diversified crop rotations resulted in increased economic output, that 15 rotations had higher EWUE, and that 11 rotations saw improvements across both dimensions relative to the conventional wheatmaize double cropping system (Figure 8). In particular, multi-year cropping systems with rotation cycles longer than 2 years and intensive non-winter wheat-based double cropping in 1 year increased annual average economic outputs and EWUEs by at least $11 \%$ and $3 \%$, respectively. In addition, some wheat-maize-based rotations that included high-value crops such as cotton and peanuts increased economic output and EWUE by as much as $13 \%$ and $40 \%$, respectively, relative to conventional wheat-maize (Figure 8; Figure S8). Winter wheat-based double cropping systems in 1 year had a similar economic output to conventional WS but a $26 \%$ lower EWUE. The perennial crop and single and rainfed cropping systems had no advantage in economic output over conventional wheat-maize (Figure 8; Figure S8). Therefore, wheat-maize-based multiple crop systems involving cash crops (cotton, peanut, sweet potato, and soybean) had better economic outputs and EWUEs, also bringing more product diversity than conventional wheat-maize. These findings point to a suite of economically viable options for improving crop rotations. Future development of more efficient, groundwater-sustainable cropping systems should consider historical patterns of land use, cropping intensity, and irrigation practices.

\section{4 | Co-benefit and trade-offs of diversified crop rotations across multiple dimensions}

Economic output, grain production per year when grain is grown, and groundwater decline all improved for certain multi-year crop rotations with a cropping index ranging between 1.25 to 1.67 (Figure 9). These crop rotations were consistently characterized by periodic fallowing, rotation cycles of more than 2 years, and the incorporation of high-value crops into the wheat-maize cycle, such as cotton, peanut,

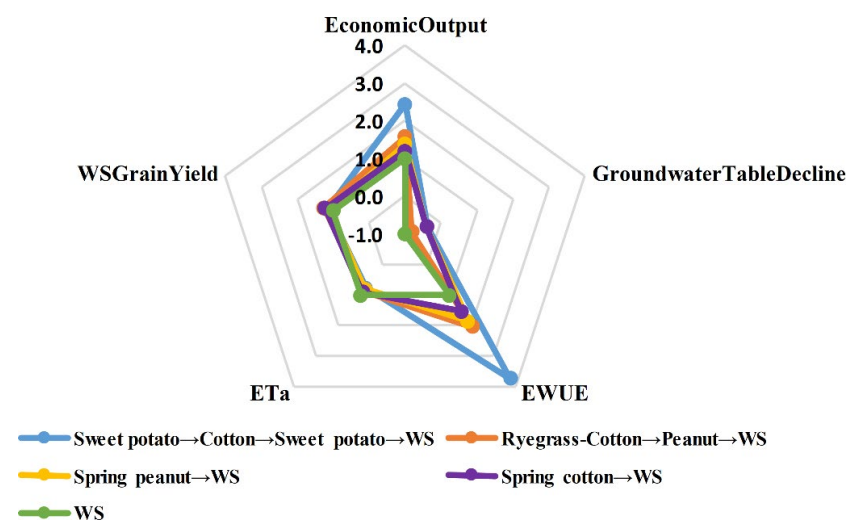

F I G U RE 9 Outcomes of alternative crop rotations for economic output, groundwater table decline, actual evapotranspiration, economic water use efficiency, and WS grain yield. WS means winter wheatsummer maize rotation, WS grain yield is the average grain yield of wheat and maize within the wheat-maize years in rotation cycles. The number of -1.0 to 4.0 is the value of each outcome for a given alternative crop rotation divided by the value of WS rotation

and sweet potato (e.g., sweet potato $\rightarrow$ cotton $\rightarrow$ sweet potato $\rightarrow$ wheat-maize rotation with five harvests in 4 years; ryegrass-cotton $\rightarrow$ peanut $\rightarrow$ wheat-maize rotation with five harvests in 3 years; spring peanut $\rightarrow$ wheat-maize rotation and spring cotton $\rightarrow$ wheat-maize rotation both with three harvests in 2 years). All of these diversified rotations achieved simultaneous benefits for economic output, grain production per year in which grain was grown, and groundwater decline (Figure 9). Specifically, they reduced $E T_{c}$ by $10 \%-23 \%$, mitigated groundwater decline by $19 \%-62 \%$, improved economic output by $20 \%-143 \%$, and increased annual average grain yield from wheat and maize within the wheatmaize years by $12 \%-22 \%$.

Lastly, we performed a principal component analysis (PCA) to examine the relationships between the configuration of crop rotations and environmental and economic outcomes (Figure 10). Systems with more wheat were associated with higher irrigation water input and greater groundwater decline, while systems with more maize were neutral in this regard. Economic output was not strongly related to irrigation water input or groundwater decline. Increasing the number of fallowing days and decreasing the cropping index (i.e., lower harvest frequency) were both associated with reduced groundwater declines (Figure 11). Together with the comparison of the multi-dimensional outcomes of alternative crop rotations, these findings confirm a pattern in which diversified crop rotations with fallow periods, a lower cropping index, and high-value crops offer the opportunity to simultaneously reduce groundwater decline, improve economic outcomes, and increase food production-all of which are essential for achieving more sustainable agriculture in the NCP. 


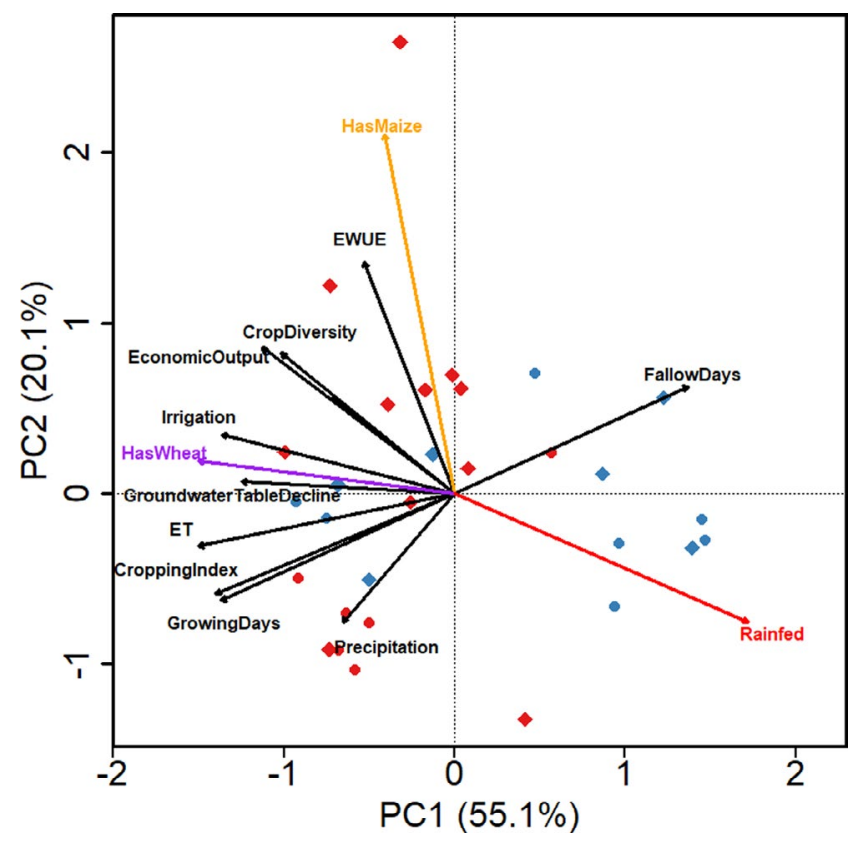

F I G URE 10 Principal component analysis of attributes of cropping systems tested in the North China Plain. Symbols in (a) represent crop rotations with (red) or without (blue) wheat, and with (rhombus) or without (circle) maize. Arrows represent continuous variables (black) and categorical variables (colored). Factor loadings are given in Table S6. Principal component analysis of the grain output, economic output, intensity of land use, and water use of different rotation systems. Principal component 1 (PC1) is mainly associated with the intensity of cropping, as characterized by cropping index (average number of harvests per year), cropping days/year, fallow days/year, ET, irrigation amount/year, and ground water decline. Economic output has a high association with these "intensity" variables. Cropping systems with wheat are characterized by high water use, groundwater table decline, and high economic output. Principle component 2 (PC2) is associated with the presence of maize and with economic water use efficiency. Cropping systems with more maize tend to have higher economic water use efficiency and crop diversity as well as positive economic output in an absolute sense

\section{4 | DISCUSSION}

\section{1 | Toward more sustainable cropping systems}

Our analysis indicates that diversifying crop rotations offers major opportunities to reduce trends of unsustainable water use in North China Plain, while keeping grain output and economic profitability at sustainable levels and greatly increasing the economic water use efficiency. Diversification of crop rotations should therefore be considered in national policymaking for food, agricultural, water, and health (Tao et al., 2020). In particular, this study identified key features of diversified cropping patterns-reducing cropping index, introducing fallow periods, and incorporating alternative high-value crops into the conventional and intensive wheat-maize double cropping system - that can help to minimize the trade-off between groundwater depletion and food production while also improving economic outcomes. While previous studies have investigated individual aspects of crop production and groundwater in the NCP (Kendy et al., 2004; Meng et al., 2017; Qin et al., 2018; Sun et al., 2014; Wang, 2011; Yan et al., 2016; Yang, 2015c; Yang, Chen, Pacenka, Gao, Ma, et al., 2015; Yang et al., 2019), our findings provide an integrated understanding of the outcomes of alternative cropping patterns across groundwater, economic, and food production dimensions. Such an approach can be readily applied to other agriculturally important world regions to investigate the opportunities for diversified cropping rotations to achieve more sustainable production systems.

This study identified that reducing the cropping indexranging from 2 for the intensive wheat-maize system to 1 for single cropping systems-introducing fallow periods, and alternating complementary crop types between intensive wheat-maize rotations can help to balance groundwater drawdown, food production, and the economic output of agriculture in the NCP. Indeed, previous studies focused on the NCP have indicated that adopting a fallow season could mitigate declining groundwater levels while maintaining yield (Liang et al., 2019; Luo et al., 2018; Van Oort et al., 2016). The efficiency of soil water accumulating during fallows and availability of that soil water for use by crops are key drivers of farming system productivity and profitability. Using fallows to accumulate soil water to buffer subsequent crops against the highly variable climate is critical in northern grain production systems (Bell et al., 2019). In a 12-year field experiment, $E T_{a}$ during the fallow period from October to April of the next year accounted for about $7-10 \%$ of annual water consumption (Yang, 2015c; Yang et al., 2019). Modified wheat-maize-based rotations with three harvests in 2 years, single-species continuous cropping, and perennial crops reduced annual $E T_{a}$ by $10 \%-54 \%$ compared to conventional wheat-maize. Single-species continuous cropping system reduced the groundwater use per year, but they do not take full advantage of the region's abundant light and heat at the cost of reducing food production (Liu \& Chen, 2005). The spring maize-summer maize rotation had higher grain yield, WUE, economic output, and EWUE than conventional winter wheat-summer maize. But this cropping system requires high accumulated temperatures, heat resources for grain filling, and an early maturing spring maize variety, which primarily occurs and is limited in the southern Hebei Province (Meng et al., 2017). Expanding this system northward would require adaptations to sowing date, plant density, and variety (Zhou, 2016). Besides, omitting winter wheat in this double maize rotation would impact national self-sufficiency in the diet (Cui \& Shoemaker, 2018). Wheat is second to rice as a source of calories in developing countries and first as a source of protein (Braun et al., 2010). Wheat currently provided $20 \%$ 


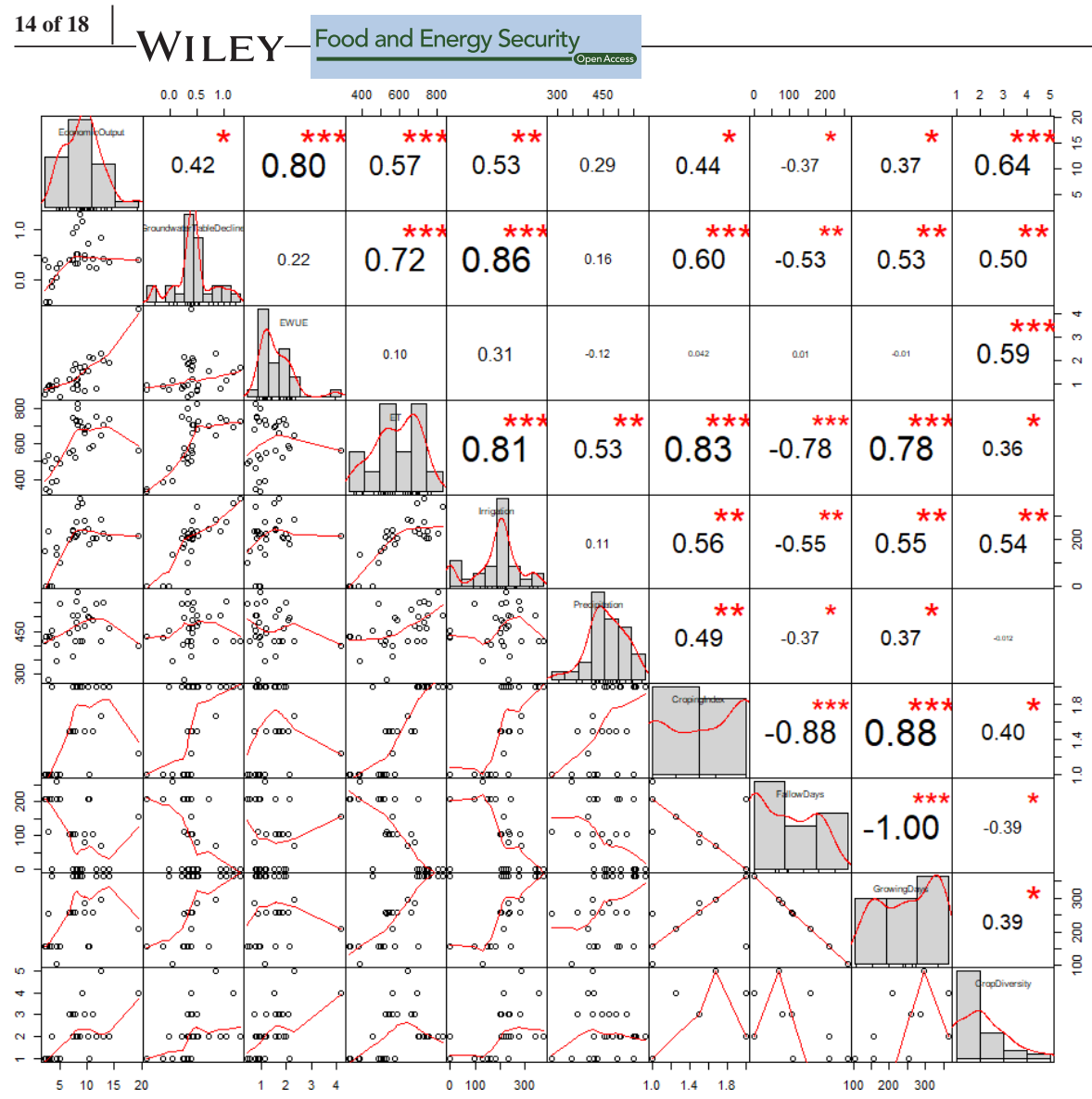

F I G URE 11 Correlation matrix of associations between food production and groundwater use in crop rotation systems. The number values in the grid are the correlation coefficients of the daily protein and of food calories for 4.5 billion people (Shewry \& Hey, 2015). Wheat production is crucial for NCP and China diets, whereas maize is mainly used for livestock feed (Yun et al., 2019). The dual maize rotation increases the maize planting frequency, which forces much better coordination between crops and livestock to harvest for silage in spring and grain in summer (Yun et al., 2019). Double maize is an unlikely candidate for a new dominant cropping system for the whole NCP. The spring maize $\rightarrow$ winter wheat-summer maize rotation with three harvests in 2 years by retaining winter wheat has more promise for saving groundwater and diet sufficiency than the double maize rotation; it is worth considering the spring maize $\rightarrow$ winter wheat-summer maize rotation as superior to WS for the future.

The mismatch between precipitation and crop water requirements of wheat-maize system-especially for winter wheat-has resulted in a groundwater table decline of $1.04 \mathrm{~m} \mathrm{year}^{-1}$. Our PCA analysis identified the cultivation of winter wheat as the primary factor contributing to groundwater table decline. As a result, the conventional wheat-maize system in the NCP is being increasingly challenged by the overdraft of water resources and climate change (Wang et al., 2008; Zhao et al., 2018). Compared to the conventional wheat-maize system, we found that $90 \%$ of the 31 rotations reduced rates of groundwater depletion, with nearly half of all alternative rotations mitigating groundwater table decline by $50 \%$ or more. Indeed, some studies have suggested reducing the winter wheat planted area by up to $76 \%$ to decrease water demands from groundwater (Gao et al., 2015; Liang et al., 2019; Meng et al., 2012; Wang et al., 2008; Xiao et al., 2017). However, the NCP produces 51\% China's wheat (National Bureau of Statistics of China, 2019b), and China strives to be self-sufficient in grains (Cui \& Shoemaker, 2018). Therefore, reductions in wheat planting area need to be considered in the context of national grain security (Cui \& Shoemaker, 2018; Liang et al., 2019). Diversified crop rotations of this study demonstrate opportunities to continue to include wheat in multi-year wheat-maize-based crop rotations while simultaneously reducing the rate of groundwater depletion, maintaining grain yields, and increasing economic outputs through the periodic incorporation of higher-value crops (Castellazzi et al., 2008). The benefits will be reinforced by developing the sustainable wheat cropping systems in which novel wheat genotypes and agronomy management must be integrated to improve soil, water, and air quality, and ensure profitability and economic security for farmers (Hunt, 2017). Kirkegaard and Hunt (2010) reported that increases in Australian wheat production have come when genotype (G) and management (M) technologies synergies to form coherent farming systems. The combination of new winter wheat genotypes with earlier establishment has the potential to deliver a new water-limited potential yield increase due to the greater rooting depth and deep soil water extraction (Flohr et al., 2020). Future climates may favor the early sowing $\times$ slow-developing cultivar $\times$ fallow management synergy for winter wheat production (Hunt et al., 2019). 
Coordinated reconfiguration of cropping patterns across regions can also serve as an effective complement to diversified cropping rotations by ensuring that national production of certain crops is not reduced (Davis et al., 2017). Meanwhile, the more sustainably diversified crop rotations should include the more efficient and nutritional crop, like $\mathrm{C} 4$ species. The stomata of $\mathrm{C} 4$ crops are much responsive to environmental changes than $\mathrm{C} 3$ species, along with the greater potential productivity and greater water use efficiency of $\mathrm{C} 4$ species (Akita \& Moss, 1972). A healthy diet should increase plant proteins (e.g., grain legumes) and include plant oils, fruits, and vegetables. Poor diets pose a greater risk to morbidity and mortality than other unhealthy habits combined (Willett et al., 2019). Adjusting the diet with more nutritive crops from the diversified crop rotations can feed the population using less water and land. Except the benefit of the diversified crop rotation to less groundwater use and maintain food production, it has the potential promoting the radical transformation of the regional or national food system.

In addition, combining alternative cropping systems combined with the updated integrated water-saving technologies including agronomic, biological, and engineering practices can serve to enhance water savings (Gan et al., 2013; Li et al., 2018; Liu et al., 2013; Meng et al., 2017; Qin et al., 2015; Xu et al., 2018; Zhang et al., 2010). Simultaneously, future development of more efficient, groundwater-sustainable cropping systems should also consider historical patterns of land use, cropping intensity, irrigation practices and self-sufficiency of food production, and a healthy diet to improve human health.

\section{2 | Prospects for crop reconfiguration, external water input, and policymaking}

Coordinated policy solutions that integrate multiple complementary strategies will be essential for moderating (or eliminating) trade-offs in the NCP, a region which plays a central role in meeting grain production targets and providing healthier diets for all of China. Our study finds that achieving more sustainable crop configurations in the NCP will require greater crop diversity-including field crops and horticultural crops - the outcomes of which should be quantified in terms of groundwater use, yield, economic profitability, energy, and nutritional value, according to Tilman and Clark (2014). These multiple metrics can be blended in a Pareto-optimality analysis (or other multi-objective balancing approaches) to uncover optimal crop choices while also ensuring that national grain production is not compromised (Ditzler et al., 2019). Other future work is required to understand the consequences of groundwater neutral cropping systems on regional food production and the reasonable allocation of national water resources. Systematic regional groundwater tracking and forecasting models tailored to the
NCP should be developed to evaluate groundwater table dynamics, considering possible lateral recharge and spatial heterogeneity of the aquifer (Yang, Chen, Pacenka, Gao, Ma, et al., 2015).

Addressing these research needs will be essential for evaluating current and planned water resource policies intended to address groundwater depletion in the NCP. One possibility is to physically import water to the region. China's SouthNorth Water Transfer (SNWT) project aims to divert water from the Yangtze River in the south to drier north regions including Beijing and its surroundings, and the central route passes through the NCP (Kattel et al., 2019). The first phase of the SNWT project was finished in 2014; the total volume of water projected to be passed through the NCP is 7.0-7.5 billion $\mathrm{m}^{3}$ year $^{-1}$ - mainly for urban domestic use, including $\sim 1.2$ billion $\mathrm{m}^{3}$ year ${ }^{-1}$ to Beijing, $\sim 1.0$ billion $\mathrm{m}^{3}$ year $^{-1}$ to Tianjin, and $\sim 3.0$ billion $\mathrm{m}^{3}$ year $^{-1}$ to Hebei province (Liang et al., 2019; Van Oort et al., 2016). While external water importation to the NCP is far beyond the scope of this study, it has been estimated that SNWT needs to provide at least $50 \%$ of the total amount of irrigation water used in current wheat-maize rotations to prevent groundwater table decline and maintain crop yields (Liang et al., 2019; Van Oort et al., 2016). This physical import of water to mitigate groundwater depletion can also be complemented by virtual water imports, as the virtual water embodied in exported agricultural goods has placed significant pressure on water resources in the NCP (Zhang et al., 2017). Planning for virtual water trading between regions can help to ensure more sustainable usage of water resources. These and other strategies-including diversified cropping patterns - can all be incorporated into a comprehensive sustainable food production strategy for the NCP and other regions of the world where groundwater is used for irrigation.

\section{5 | CONCLUSION}

This study conducted an integrated analysis of the outcomes of diversified cropping systems for the multiple dimensions of groundwater use, economic output, and food production. Wheat-maize-based multiple cropping systems with rotation cycles of more than 2 years, a cropping index lower than 2 , periodic fallowing, and incorporation of high-value crops decreased $E T_{a}$ by $\sim 31 \%$, mitigated groundwater table decline by $19 \%-67 \%$, and increased annual averaged economic outputs and EWUEs by at least $11 \%$ and 3\%, respectively, relative to conventional wheat-maize double cropping. These results point to the possibility of benefits across multiple dimensions including increased food production, more sustainable groundwater use, and improved farmer benefits in the NCP when more diversified cropping systems are adopted. The study provides strong empirical evidence for diversified crop 
rotations to achieve more sustainable production systems in the North China Plain and promising insights for similar solutions in other agriculturally important areas in the world.

\section{ACKNOWLEDGMENTS}

This work was jointly financed by the National Natural Science Foundation of China (No. 32071975, No. 51861125103 and No. 31601267) and Hebei Province Key Research and Development Program of China (20326411D-1).

\section{CONFLICT OF INTEREST}

The authors declare no conflict of interest.

\section{ORCID}

Xiaolin Yang (1D) https://orcid.org/0000-0001-9146-8722

Taisheng Du (1) https://orcid.org/0000-0002-6146-0217

\section{REFERENCES}

Akita, S., \& Moss, D. N. (1972). Differential stomatal response between $\mathrm{C} 3$ and $\mathrm{C} 4$ species to atmospheric $\mathrm{CO} 2$ concentration and light1. Crop Science, 12(6), cropsci1972.0011183X001200060022x. https://doi.org/10.2135/cropsci1972.0011183X001200060022x.

Bell, L., Erbacher, A., Lawrence, D., Verrell, A., Baird, J., Aisthorpe, D., Zull, A., Gentry, J., Brooke, G., \& Klepper, K. (2019) Impacts of crops and crop sequences on soil water accumulation and use. Retrieved from https://grdc.com.au/resources-and-publications/ grdc-update-papers/tab-content/grdc-update-papers/2019/02/ impacts-of-crops-and-crop-sequences-on-soil-water-accumulati on-and-use

Braun, H. J., Atlin, G., \& Payne, T. (2010). Multi-location testing as a tool to identify plant response to global climate change. In M. P. Reynolds (Ed.), Climate change and crop production (pp. 115138). CABI. (Reprinted).

Cao, G. L., Zheng, C. M., Scanlon, B. R., Liu, J., \& Li, W. P. (2013). Use of flow modeling to assess sustainability of groundwater resources in the North China Plain. Water Resources Research, 49(1), 159175. https://doi.org/10.1029/2012WR011899

Castellazzi, M. S., Wood, G. A., Burgess, P. J., Morris, J., Conrad, K. F., \& Perry, J. N. (2008). A systematic representation of crop rotations. Agricultural Systems, 97(1-2), 26-33. https://doi.org/10.1016/j. agsy.2007.10.006

Chen, C., Wang, E. L., Yu, Q., Green, T. R., Yu, Q. A., Ma, L. W., \& Wang, T. D. (2010). Modelling the effects of climate variability and water management on crop water productivity and water balance in the North China Plain. Agricultural Water Management, 97(8), 1175-1184. https://doi.org/10.1016/j.agwat.2008.11.012

Chen, S. Y., Zhang, X. Y., Shao, L. W., Sun, H. Y., \& Niu, J. F. (2015). A comparative study of yield, cost-benefit and water use efficiency between monoculture of spring maize and double crops of wheatmaize under rain-fed condition in the North China Plain. Chinese Journal of Eco-Agriculture, 23(5), 535-543.

China Water Resources Bulletin (2019). China Water Resources Bulletin 1975-2018. Ministry of Water Resources of the People's Republic of China.

Cui, K., \& Shoemaker, S. P. (2018). A look at food security in China. $n p j$ Science of Food, 2, 4. https://doi.org/10.1038/s41538-018-0012-x
Davis, K. F., Rulli, C. M., Seveso, A., \& D'Odorico, P. (2017). Increased food production and reduced water use through optimized crop distribution. Nature Geoscience, 10(12), 919-924. https://doi. org/10.1038/s41561-017-0004-5

de Graaf, I. E. M., Gleeson, T., Rens Van Beek, L. P. H., Sutanudjaja, E. H., \& Bierkens, M. F. P. (2019). Environmental flow limits to global groundwater pumping. Nature, 574(7776), 90-94. https:// doi.org/10.1038/s41586-019-1594-4

Ditzler, L., Komarek, A. M., Chiang, T., Alvarez, S., Chatterjee, S. A., Timler, C., Raneri, J. E., Carmona, N. E., Kennedy, G., \& Groot, J. C. J. (2019). A model to examine farm household trade-offs and synergies with an application to smallholders in Vietnam. Agricultural Systems, 173, 49-63. https://doi.org/10.1016/j. agsy.2019.02.008

Famiglietti, J. S. (2014). The global groundwater crisis. Nature Climate Change, 4, 945-948. https://doi.org/10.1038/nclimate2425

Flohr, B. M., Hunt, J. R., Kirkegaard, J. A., Rheinheimer, B., Swan, T., Goward, L., Evans, J. R., \& Bullock, M. (2020). Deep soil wateruse determines the yield benefit of long-cycle wheat. Frontiers in Plant Science, 11, 548. https://doi.org/10.3389/fpls.2020.00548

Gan, Y. T., Siddique, K. H. M., Turner, N. C., Li, X. G., Niu, J. Y., Yang, C., Liu, L., \& Chai, Q. (2013). Ridge-furrow mulching systems -an innovative technique system for boosting crop productivity in semiarid rainfed environments. Advances in Agronomy, 118, 429476. https://doi.org/10.1016/B978-0-12-405942-9.00007-4

Gao, B., Ju, X. T., Meng, Q. F., Cui, Z. L., Christie, P., Chen, X. P., \& Zhang, F. S. (2015). The impact of alternative cropping systems on global warming potential, grain yield and groundwater use. Agriculture, Ecosystems \& Environment, 203, 46-54. https://doi. org/10.1016/j.agee.2015.01.020

Guo, B. Q., Tao, H. B., Sheng, Y. H., Wang, P., Knozer, H., \& Claupein, W. (2013). Water and nitrogen utilization of different cropping production systems in North China Plain. Journal of Maize Sciences, 21(6), 95-100,106. https://doi.org/10.3969/j. issn. 1005-0906.2013.06.021

Guo, B. Q., Tao, H. B., Wang, P., Knorzer, H., \& Claupein, W. (2013). Water utilization of different cropping production systems in North China Plain. Journal of China Agricultural University, 18(1), $53-60$.

Hunt, J. R. (2017). Winter wheat cultivars in Australian farming systems: A review. Crop and Pasture Science, 68(6), 501-515. https:// doi.org/10.1071/CP17173

Hunt, J. R., Lilley, J. M., Trevaskis, B., Flohr, B. M., Peake, A., Fletcher, A., Zwart, A. B., Gobbett, D., \& Kirkegaard, J. A. (2019). Early sowing systems can boost Australian wheat yields despite recent climate change. Nature Climate Change, 9(3), 244-247. https:// doi.org/10.1038/s41558-019-0417-9

Kattel, G. R., Shang, W., Wang, Z., \& Langford, J. (2019). China's South-to-North Water Diversion Project empowers sustainable water resources system in the North. Sustainability, 11(13), 3735. https://doi.org/10.3390/su11133735

Kendy, E., Gérard-Marchant, P., Walter, M. T., Zhang, Y. Q., Liu, C. M., \& Steenhuis, T. S. (2003). A soil-water-balance approach to quantify groundwater recharge from irrigated cropland in the North China Plain. Hydrological Processes, 17(10), 2011-2031. https:// doi.org/10.1002/hyp.1240

Kendy, E., Zhang, Y. Q., Liu, C. M., Wang, J. X., \& Steenhuis, T. S. (2004). Groundwater recharge from irrigated cropland in the North China Plain: case study of Luancheng County, Hebei Province, 
1949-2000. Hydrological Processes, 18(12), 2289-2302. https:// doi.org/10.1002/hyp.5529

Kirkegaard, J. A., \& Hunt, J. R. (2010). Increasing productivity by matching farming system management and genotype in waterlimited environments. Journal of Experimental Botany, 61(15), 4129-4143. https://doi.org/10.1093/jxb/erq245

Li, J. P., Xu, X. X., Lin, G., Wang, Y. Q., Liu, Y., Zhang, M., Zhou, J. Y., Wang, Z. M., \& Zhang, Y. H. (2018). Micro-irrigation improves grain yield and resource use efficiency by co-locating the roots and N-fertilizer distribution of winter wheat in the North China Plain. Science of the Total Environment, 643, 367-377. https://doi. org/10.1016/j.scitotenv.2018.06.157

Li, P., \& Ren, L. (2019). Evaluating the effects of limited irrigation on crop water productivity and reducing deep groundwater exploitation in the North China Plain using an agro-hydrological model: II. Scenario simulation and analysis. Journal of Hydrology, 574, 715-732. https://doi.org/10.1016/j.jhydrol.2019.03.034

Liang, H., Qin, W., Hu, K. L., Tao, H. B., \& Li, B. G. (2019). Modelling groundwater level dynamics under different cropping systems and developing groundwater neutral systems in the North China Plain. Agricultural Water Management, 213, 732-741. https://doi. org/10.1016/j.agwat.2018.11.022

Liu, C. M., Yu, J. J., \& Eloise, K. (2001). Groundwater exploitation and its impact on the environment in the North China Plain. Water International, 26(2), 265-272. https://doi.org/10.1080/02508 060108686913

Liu, H. J., Kang, Y. H., Yao, S. M., Sun, Z. Q., Liu, S. P., \& Wang, Q. G. (2013). Field evaluation on water productivity of winter wheat under sprinkler or surface irrigation in the North China Plain. Irrigation and Drainage, 62(1), 37-49. https://doi.org/10.1002/ ird.1712

Liu, M., Tao, H. B., Wang, P., Lü, L. H., Zhang, Y. J., \& Zhang, L. (2008). Water consumption, soil water content variation and water utilization efficiency of different cropping system in China. Journal of Soil and Water Conservation, 22(2), 116-121. https:// doi.org/10.1016/S0301-472X(98)00058-7

Liu, M. Y., \& Wang, Y. X. (1994). Balance between exploitation and supply of underground water resources and plantin system in Heilonggang Region. Agricultural Research in the Arid Areas, 12(3), 79-84.

Liu, X. H., \& Chen, F. (2005). Farming sytems in China. China Agriculture Press.

Luo, J. M., Shen, Y. J., Qi, Y. Q., Zhang, Y. C., \& Xiao, D. P. (2018). Evaluating water conservation effects due to cropping system optimization on the Beijing-Tianjin-Hebei plain, China. Agricultural Systems, 159, 32-41. https://doi.org/10.1016/j.agsy.2017.10.002

Meng, Q. F., Sun, Q. P., Chen, X. P., Cui, Z. L., Yue, S. C., Zhang, F. S., \& Römheld, V. (2012). Alternative cropping systems for sustainable water and nitrogen use in the North China Plain. Agriculture, Ecosystems \& Environment, 146(1), 93-102. https:// doi.org/10.1016/j.agee.2011.10.015

Meng, Q. F., Wang, H. F., Yan, P., Pan, J. X., Lu, D. J., Cui, Z. L., Zhang, F. S., \& Chen, X. P. (2017). Designing a new cropping system for high productivity and sustainable water usage under climate change. Scientific Reports, 7(1), 41587. https://doi.org/10.1038/ srep41587

National Bureau of Statistics of China (2019a). China statistical yearbook 2018. China Statistics Press.

National Bureau of Statistics of China (2019b). China Rural Statistical Yearbook 2018. China Statistics Press.
National Meteorological Information Centre (2019). Meteorological data sharing service system. Retrieved from http://www.nmic.cn/

Oksanen, J. F., Blanchet, G., Friendly, M., Kindt, R., Legendre, P., McGlinn, D., Minchin, P. R., Hara, R. B. O., Simpson, G. L., Solymos, P., Henry, M., \& Helene, W. (2017). vegan: Community Ecology Package. R package version 2.4-3. Retrieved from https:// cran.r-project.org, https://github.com/vegandevs/vegan

Pei, H., Scanlon, B. R., Shen, Y., Reedy, R. C., Long, D., \& Liu, C. (2015). Impacts of varying agricultural intensification on crop yield and groundwater resources: Comparison of the North China Plain and US High Plains. Environmental Research Letters, 10(4), 44013. https://doi.org/10.1088/174 $8-9326 / 10 / 4 / 044013$

Qin, W., Hu, C. S., \& Oenema, O. (2015). Soil mulching significantly enhances yields and water and nitrogen use efficiencies of maize and wheat: a meta-analysis. Scientific Reports, 5(1), 16210. https:// doi.org/10.1038/srep16210

Qin, W. L., Zhang, X. Y., Chen, S. Y., Sun, H. Y., \& Shao, L. W. (2018). Crop rotation and $\mathrm{N}$ application rate affecting the performance of winter wheat under deficit irrigation. Agricultural Water Management, 210, 330-339. https://doi.org/10.1016/j. agwat.2018.08.026

R Core Team (2014). R: A language and environment for statistical computing. R Foundation for Statistical Computing. Retried from http://www.Rproject.org/

Shewry, P. R., \& Hey, S. J. (2015). The contribution of wheat to human diet and health. [Review; Journal Article]. Food Energy Secur, 4(3), 178-202. https://doi.org/10.1002/fes3.64

Sun, H. Y., Liu, C. M., Zhang, X. Y., Shen, Y. J., \& Zhang, Y. Q. (2006). Effects of irrigation on water balance, yield and WUE of winter wheat in the North China Plain. Agricultural Water Management, $85(1-2), \quad 211-218$. https://doi.org/10.1016/j. agwat.2006.04.008

Sun, H. Y., Liu, X. J., Shao, L. W., Chen, S. Y., Liu, X. W., \& Zhang, X. Y. (2014). Effects of different cropping pattern on ground water and economic water use efficiency in the Hebei Low Plain. [Effects of Different Cropping Pattern on Ground Water and Economic Water Use Efficiency in the Hebei Low Plain]. Chinese Agricultural Science Bulletin, 30(32), 214-220.

Sun, H. Y., Zhang, X. Y., Liu, X. J., Liu, X. W., Shao, L. W., Chen, S. Y., Wang, J. T., \& Dong, X. L. (2019). Impact of different cropping systems and irrigation schedules on evapotranspiration, grain yield and groundwater level in the North China Plain. Agricultural Water Management, 211, 202-209. https://doi.org/10.1016/j. agwat.2018.09.046

Sun, H. Y., Zhang, X. Y., Wang, E. L., Chen, S. Y., \& Shao, L. W. (2015). Quantifying the impact of irrigation on groundwater reserve and crop production-A case study in the North China Plain. European Journal of Agronomy, 70(1), 48-56. https://doi. org/10.1016/j.eja.2015.07.001

Sun, Q. P., Kröbel, R., Müller, T., Römheld, V., Cui, Z. L., Zhang, F. S., \& Chen, X. P. (2011). Optimization of yield and water-use of different cropping systems for sustainable groundwater use in North China Plain. Agricultural Water Management, 98(5), 808-814. https://doi.org/10.1016/j.agwat.2010.12.007

Tao, S. L., Zhang, H., Feng, Y. H., Zhu, J. L., Cai, Q., Xiong, X. Y., Ma, S. H., Fang, L. Q., Fang, W. J., Tian, D., Zhao, X., \& Fang, J. Y. (2020). Changes in China's water resources in the early 21 st century. Frontiers in Ecology and the Environment, 18(4), 188-193. https://doi.org/10.1002/fee.2164 
Tilman, D., \& Clark, M. (2014). Global diets link environmental sustainability and human health. Nature, 515(7528), 518-522. https:// doi.org/10.1038/nature13959

Van Oort, P. A. J., Wang, G., Vos, J., Meinke, H., Li, B. G., Huang, J. K., \& van der Werf, W. (2016). Towards groundwater neutral cropping systems in the Alluvial Fans of the North China Plain. Agricultural Water Management, 165, 131-140. https://doi.org/10.1016/j. agwat.2015.11.005

Wang, D. (2018b). Ecosystem services evaluation of maize-based multicropping systems in North China Plain. Master Thesis. China Agricultural University.

Wang, E. L., Yu, Q., Wu, D. R., \& Xia, J. (2008). Climate, agricultural production and hydrological balance in the North China Plain. International Journal of Climatology, 28(14), 1959-1970. https:// doi.org/10.1002/joc.1677

Wang, H. X. (2011). Study on resource-saving cropping systems in northern region of Huang-huai-hai Plain. Master Thesis. China Academy of Agricultural Sciences.

Wang, J. D., Zhang, Y. Q., Gong, S. H., Xu, D., Juan, S., \& Zhao, Y. F. (2018a). Evapotranspiration, crop coefficient and yield for dripirrigated winter wheat with straw mulching in North China Plain. Field Crops Research, 217, 218-228. https://doi.org/10.1016/j. fcr.2017.05.010

Willett, W., Rockström, J., Loken, B., Springmann, M., Lang, T., Vermeulen, S., Garnett, T., Tilman, D., DeClerck, F., Wood, A., Jonell, M., Clark, M., Gordon, L. J., Fanzo, J., Hawkes, C., Zurayk, R., Rivera, J. A., De Vries, W., Majele Sibanda, L., ... Murray, C. J. L. (2019). Food in the Anthropocene: The EATLancet Commission on healthy diets from sustainable food systems. The Lancet, 393(10170), 447-492. https://doi.org/10.1016/ S0140-6736(18)31788-4

Xiao, D. P., Shen, Y. J., Qi, Y. Q., Moiwo, J. P., Min, L. L., Zhang, Y. C., Guo, Y., \& Pei, H. W. (2017). Impact of alternative cropping systems on groundwater use and grain yields in the North China Plain Region. Agricultural Systems, 153, 109-117. https://doi. org/10.1016/j.agsy.2017.01.018

Xu, X. X., Zhang, M., Li, J. P., Liu, Z. Q., Zhao, Z. G., Zhang, Y. H., Zhou, S. L., \& Wang, Z. M. (2018). Improving water use efficiency and grain yield of winter wheat by optimizing irrigations in the North China Plain. Field Crops Research, 221, 219-227. https://doi.org/10.1016/j.fcr.2018.02.011

Yan, P., Chen, Y. Q., Zhang, X. P., Tao, Z. Q., Yang, X. L., \& Sui, P. (2016). Security of water-ecology and food under replacement of winter wheat-summer maize rotation with spring maize mono-cropping in Hebei Lowland Plains. Chinese Journal of EcoAgriculture, 24(11), 1491-1499.

Yang, X. L. (2015c). Effects of diversified crop rotations on conserving groundwater resource and lowering carbon footprint in the North China Plain. PhD Dissertation. China Agricultural University.

Yang, X. L., Chen, Y. Q., Pacenka, S., Gao, W. S., Ma, L., Wang, G. Y., Yan, P., Sui, P., \& Steenhuis, T. S. (2015). Effect of diversified crop rotations on groundwater levels and crop water productivity in the North China Plain. Journal of Hydrology, 522, 428-438. https://doi.org/10.1016/j.jhydrol.2015.01.010

Yang, X. L., Chen, Y. Q., Pacenka, S., Gao, W. S., Zhang, M., Sui, P., \& Steenhuis, T. S. (2015). Recharge and groundwater use in the North China Plain for six irrigated crops for an eleven year period. PLoS One, 10(1), e0115269. https://doi.org/10.1371/journ al.pone.0115269

Yang, X. L., Chen, Y. Q., Pacenka, S., Steenhuis, T. S., \& Sui, P. (2019). Managing food and bioenergy crops with declining groundwater levels in the North China Plain. Field Crops Research, 234, 1-14. https://doi.org/10.1016/j.fcr.2019.02.003

Yun, L., Li, J., Hou, R. X., Sun, Z. G., Cong, P. F., Liang, R. B., Hang, S., Gong, H. R., \& Ouyang, Z. (2019). Emergy-based sustainability analysis of an ecologically integrated model with maize planting for silage and pig-raising in the North China Plain. Sustainability, 11(22), 6485. https://doi.org/10.3390/su11226485

Zhang, X. Y., Chen, S. Y., Sun, H. Y., Wang, Y. M., \& Shao, L. W. (2010). Water use efficiency and associated traits in winter wheat cultivars in the North China Plain. Agricultural Water Management, 97(8), 1117-1125. https://doi.org/10.1016/j.agwat.2009.06.003

Zhang, X. Y., Pei, D., \& Hu, C. S. (2003). Conserving groundwater for irrigation in the North China Plain. Irrigation Science, 21(4), 159166. https://doi.org/10.1007/s00271-002-0059-X

Zhang, Y. Q., Eloise, K., Yu, Q., Liu, C. M., Shen, Y. J., \& Sun, H. Y. (2004). Effect of soil water deficit on evapotranspiration, crop yield, and water use efficiency in the North China Plain. Agricultural Water Management, 64(2), 107-122. https://doi. org/10.1016/S0378-3774(03)00201-4

Zhang, Z. Y., Yang, H., \& Shi, M. J. (2017). Alleviating water scarcity in the North China Plain: The role of virtual water and real water transfer. The Chinese Economy: Chinese Food, Agricultural and Rural Economics, 50(3), 205-219. https://doi.org/10.1080/10971 475.2017.1297656

Zhao, Z. G., Qin, X., Wang, Z. M., \& Wang, E. L. (2018). Performance of different cropping systems across precipitation gradient in North China Plain. Agricultural and Forest Meteorology, 259, 162-172. https://doi.org/10.1016/j.agrformet.2018.04.019

Zhou, W. L. (2016). Evaluation of nutrients and water use efficiency of different maize weat cropping systems in the North China Plain. PhD Thesis. China Agricultural University.

Zhu, Y., Chen, Y. L., Gong, X. F., Peng, Y. N., Wang, Z. Y., \& Ji, B. (2018). Plastic film mulching improved rhizosphere microbes and yield of rainfed spring wheat. Agricultural and Forest Meteorology, 263, 130-136. https://doi.org/10.1016/j.agrformet.2018.08.015

Zuur, A., Ieno, E., Walker, N., Saveliev, A., \& Smith, G. (2009). Mixed effects models and extensions in ecology with $R$. Springer Science $\&$ Business Media.

\section{SUPPORTING INFORMATION}

Additional supporting information may be found online in the Supporting Information section.

How to cite this article: Yang, X., Steenhuis, T. S., Davis, K. F., van der Werf, W., Ritsema, C. J., Pacenka, S., Zhang, F., Siddique, K. H. M., \& Du, T. (2021). Diversified crop rotations enhance groundwater and economic sustainability of food production. Food and Energy Security, 00, e311. https://doi.org/10.1002/fes3.311 